PALEO

Revue d'archéologie préhistorique

30-1 | 2019

Varia

\title{
The Paleolithic Burials at Qafzeh Cave, Israel
}

Les sépultures paléolithiques de la grotte de Qafzeh, Israël

\section{Bernard Vandermeersch and Ofer Bar-Yosef}

\section{OpenEdition}

\section{Journals}

Electronic version

URL: http://journals.openedition.org/paleo/4848

DOI: 10.4000/paleo.4848

ISSN: 2101-0420

\section{Publisher}

SAMRA

\section{Printed version}

Date of publication: 30 December 2019

Number of pages: 256-275

ISSN: 1145-3370

\section{Electronic reference}

Bernard Vandermeersch and Ofer Bar-Yosef, « The Paleolithic Burials at Qafzeh Cave, Israel », PALEO

[Online], 30-1 | 2019, Online since 29 May 2020, connection on 10 December 2020. URL : http:// journals.openedition.org/paleo/4848 ; DOI : https://doi.org/10.4000/paleo.4848

\section{(c) (i) (9)}

PALEO est mis à disposition selon les termes de la licence Creative Commons Attribution - Pas d'Utilisation Commerciale - Pas de Modification 4.0 International. 
THE PALEOLITHIC

BURIALS

AT QAFZEH CAVE,

ISRAEL

\section{Bernard Vandermeerscha \\ Ofer Bar-Yosef ${ }^{b}$}

a. UMR 5199, PACEA, Université de Bordeaux, CNRS, Ministère de la Culture, bât. B8. Allée Geoffroy Saint-Hilaire - CS 50023, FR-33615 Pessac cedexvanderm13@gmail.com

b. Department of Anthropology, Harvard University, Cambridge, MA 02138, USA.
Human fossils, morphologically recognized as modern, were uncovered and dated at Qafzeh cave (Israel). This classification demonstrated that Mousterian industries of Middle Paleolithic age were made by populations different from those (i.e. Neanderthals) who produced similar technocomplexes in Europe. The Qafzeh excavations (during 1933-1935 and 1965-1979) followed that previously made in Skhul cave (Mt. Carmel). The Skhul and Qafzeh clusters were dated by TL and ESR readings to the time range of ca. 120-90 Ka BP.

While the morphological attributes of the Qafzeh human group became well-known through a series of publications, the ensemble of the burials and their contexts were not published in detail. The goal of this paper is to describe and discuss the information collected during the excavations of the human remains at Qafzeh cave with the aim to offer a few possible interpretations concerning the funerary practices. We have primarily employed our field observations gathered during 1965-1977, raising several hypotheses as regards our more recent comments associated with the published literature.
PALE0 30 | t. 1

DÉCEMBRE 2019

PAGES 256 À 275

KEY-WORDS Qafzeh, burials, Middle Paleolithic, Mousterian, Anatomically Modern humans, Near East, Levant. 
Les sépultures paléolithiques de la grotte de Qafzeh, Israël

La grotte de Qafzeh (Galilée, Israël) a livré, au cours de fouilles conduites en 1934/1935 et de 1965 à 1979, une importante série de fossiles humains de morphologie moderne accompagnée d'une industrie moustérienne semblable à celle produite en Europe par les Néandertaliens. Ces découvertes succèdent à celles provenant de la grotte de Skhul (1931-1932, Mont Carmel, Israël), elles aussi de morphologie moderne. Ces deux gisements sont datés (TL et ESR) de 120 à 90 ky BP.

Alors que les fossiles de Qafzeh ont été largement décrits, leurs contextes, en particulier les sépultures, n'ont pas été publiés en détail. Deux d'entre elles sont exceptionnelles dans un niveau moustérien et les données chronologiques et archéologiques sont en faveur d'une occupation relativement courte du site au Paléolithique moyen. L'objectif de ce travail est de présenter les données recueillies au cours des fouilles récentes et des fouilles de Neuville/Stekelis sur les restes humains et les interprétations que l'on peut en déduire quant aux pratiques funéraires de cette population.
MOTS-CLÉS Qafzeh, sépultures, Paléolithique moyen, Moustérien, Hommes anatomiquement modernes, Proche-Orient, Levant.

\section{1 | THE CAVE AND THE HISTORY OF ITS EXCAVATIONS}

Since the mid-19 ${ }^{\text {th }}$ century the discoveries of human remains in archaeological contexts have attracted the attention of scholars and media alike. The first human fossil (recovered in 1856) to be recognized as such, at least by some scholars, was considered to represent a past human species, the Neanderthals (King 1864). With the expansion of excavations in Middle Paleolithic sites in European caves and rock shelters the Neanderthal burials as well as scattered bones and teeth were associated with various Mousterian industries. However, since the 1930's the morphology of the skeletal remains in Skhul cave (Mt. Carmel: Garrod and Bate 1937; McCown and Keith 1939) and Qafzeh cave (Galilee: Neuville 1951; Vallois and Vandermeersch 1972) though deriving from Middle Palaeolithic, Mousterian contexts, was acknowledged as heralding the presence of anatomically modern human characteristics (e.g., Howell 1958, 1959; Vandermeersch 1981; Trinkaus 1984). The morphological comparisons of Neanderthals and the so-called "Proto Cro-Magnons" (Howell, 1958, 1959) had clearly indicated that different kinds of people produced generally similar lithic tool-kits in both regions. Further discoveries in the Levant such as those at Amud, Kebara and Dederiyeh caves as well as in the western Zagros mountains (e.g., Shanidar cave; ie Solecki 1971; Trinkaus 1983) demonstrated that the fossils classified as Neanderthals were also present in southwestern Asia. Readings of Electron Spin Resonance (ESR) and Thermoluminescence (TL) dating techniques indicated that the Skhul-Qafzeh fossils are earlier than the local, Levantine, Neanderthal remains, and apparently were absent in western Europe (Valladas et al. 1987, 1988; Schwarcz et al. 1988)

In the search for similarities and differences between the material culture of these two populations, attention was payed also to other aspects, such as the nature of subsistence strategies, ephemeral and stable occupations, and funerary practices. Once scholars were generally satisfied with the overall evolutionary cultural trends during the Middle Paleolithic period, the latter issues became the focus of intensive scrutiny. Non-critical acceptance of excavators' observations as described in the published reports was not considered a sufficient answer to the question of "how did complete human skeletons become part of the archaeological contexts?'

Even though the cultural trends may serve as solid testimony for intentionality, funerary practices became a focal issue of study. The basic requirement was to trace the process of the internment, the degree of the preservation of the fossils, the role of taphonomic processes in their preservation and/or destruction, including impacts by post-depositional processes. These issues will be discussed below in reference to the Qafzeh Cave burials, following a short presentation of the history of the excavations, stratigraphy and dates, before launching the description and interpretation of the burials. The lithic industries and faunal records of this site had already been published in detail (Haas 1972; Tchernov 1989; Rabinovich and Tchernov 1995; Hovers 2009). We have included in our discussions only aspects directly relevant to the main topic of this paper. 
Qafzeh cave (fig. 1) is located at the flank of a hill near Nazareth, in Wadi el-Hajj, on the south-west side of the mountain, $220 \mathrm{~m}$ above sea level and seven meters above the wadi. It is a large cave where the main chamber measures $27 \mathrm{~m}$ by $17 \mathrm{~m}$ and opens through a $5 \mathrm{~m}$ wide porch that extends into a large open terrace. The excavations uncovered a limestone step marking a sharp topographic drop of $1.5 \mathrm{~m}$ that originally separated the inner chamber and its depositional history from the one of the terrace. This natural threshold is located today beyond the current entrance of the cave.

René Neuville and Moshe Stekelis conducted the first excavations in Qafzeh from 1933 to 1935 (fig.2). Most of their field operation concerned first the inside of the cave that was divided into sections, without the use of a grid, a common approach by researchers at that time. The stratigraphy exposed in the inner area included layers from present day through the Upper and Middle Paleolithic. One human frontal bone was found in a disturbed layer (Qafzeh 1), and the front part of a skullcap and mandible fragments (Qafzeh 2) were found in situ in an Upper Paleolithic context (Vandermeersch et al. 2013).

The overall depositional sequence (from the top to the base) was first labeled as consecutive stratigraphy from A to $\mathrm{M}$ combining the area inside the cave with the outdoor terrace. Before the end of the last season a deep sounding further outside on the Terrace was excavated to bedrock. Further subdivision had indicated (fig. 3) that Layers A-B represent historical periods, Layers $C$ through $\mathrm{E}$ the Upper Paleolithic, and layer $\mathrm{F}$ portrays a Middle Paleolithic occupation. Layers $G$ though $M$ were identified both inside and outside the main chamber, and originally referred to as "Levalloisian", according to the cultural concepts of the 1930's (Neuville 1934, 1951). Based on maps of these early excavations we estimate the overall area excavated to bedrock at ca. $100 \mathrm{~m}^{2}$ (fig. 4). Given the different depths of the excavations in various areas, we estimated the removed volume as approximately $300 \mathrm{~m}^{3}$.

Due to the threat of a rockslide from the chimney at the back of the cave, which was filled with large limestone blocks already putting pressure on the adjacent archaeological layers, the center of the original operation was moved to the Terrace. The terrace was explored across approximately 45-50 $\mathrm{m}^{2}$ to a depth of slightly over 3 meters. Bedrock was attained mainly in the entrance area. A deep, oval-shaped sounding was excavated on the Terrace away from the edge of the excavations. The volume extracted is estimated at ca.120 $\mathrm{m}^{3}$. These excavations unearthed the remains of seven individuals, two attributed to the Upper Paleolithic (1-2) and five (3-7) to the Middle Paleolithic.

The excavations of Neuville and Stekelis were suspended due to the Arab revolt in Palestine. The human remains were entrusted to Marcelin Boule at the Institute of Human Paleontology in Paris. Sadly, he had passed away in 1942 while waiting for the excavations to resume and the delivery of the archeological and chronological information. There were also delays in the analysis of the finds due to various circumstances. R. Neuville, being a professional diplomat, spent the years of the Second World War in Morocco and came back to Palestine to complete his research in the Judean Desert, resuming the excavations at Oum Qatafa. His major publication entitled "Le Paléolithique et le Mésolithique du désert de Judée" (Neuville 1951), was published just prior to his death, by the Institute of Human Paleontology in Paris. This volume includes a short chapter on his work at Qafzeh cave.

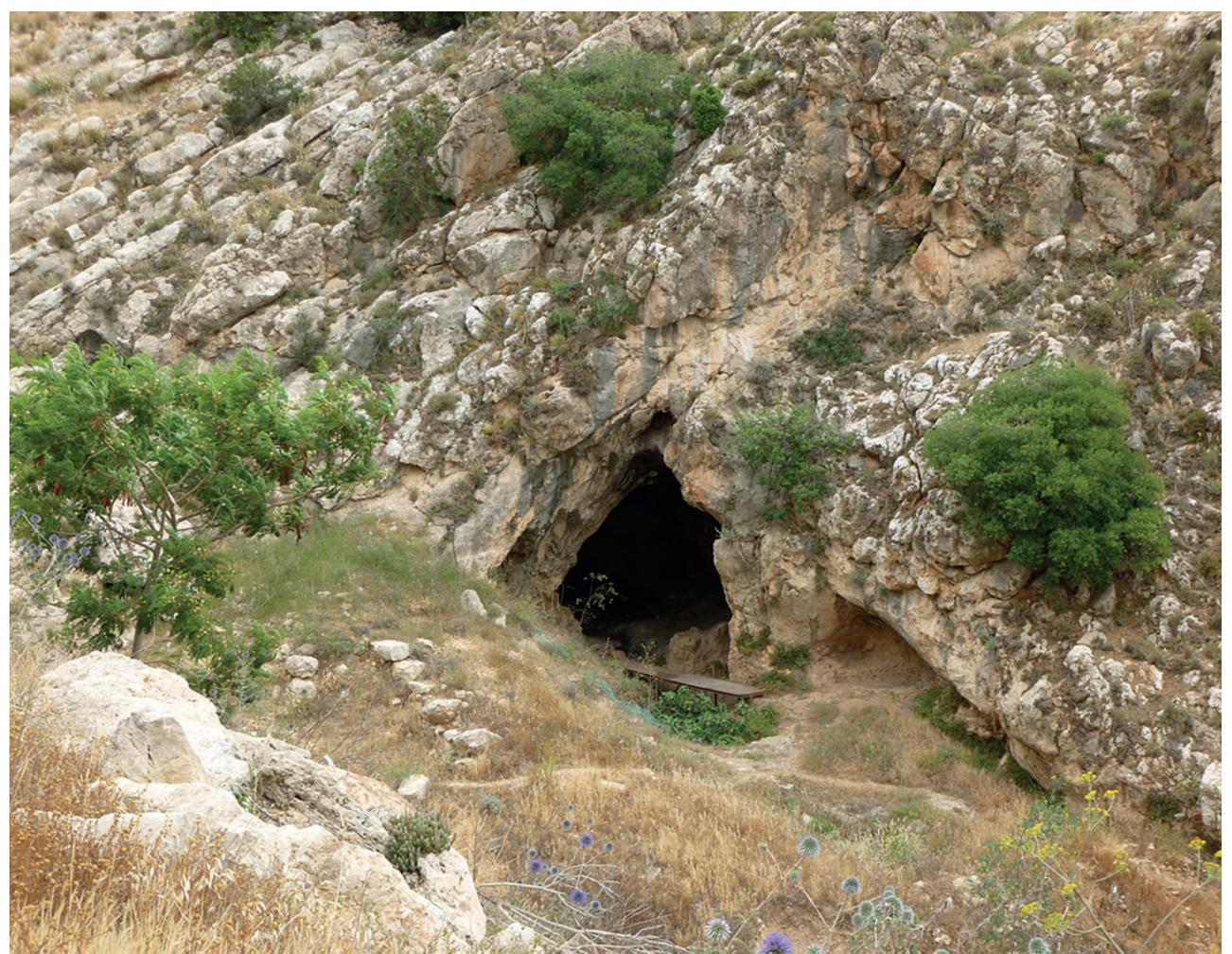

\section{FIGURE 1}

The cave of Qafzeh seen from the South. Behind the footbridge, we see the rocky threshold that separates the terrace from the cave.line. (photo: Qafzeh archives).

La grotte de Qafzeh vue du sud. On voit, derrière la passerelle, le seuil rocheux qui sépare la terrasse de la grotte. 


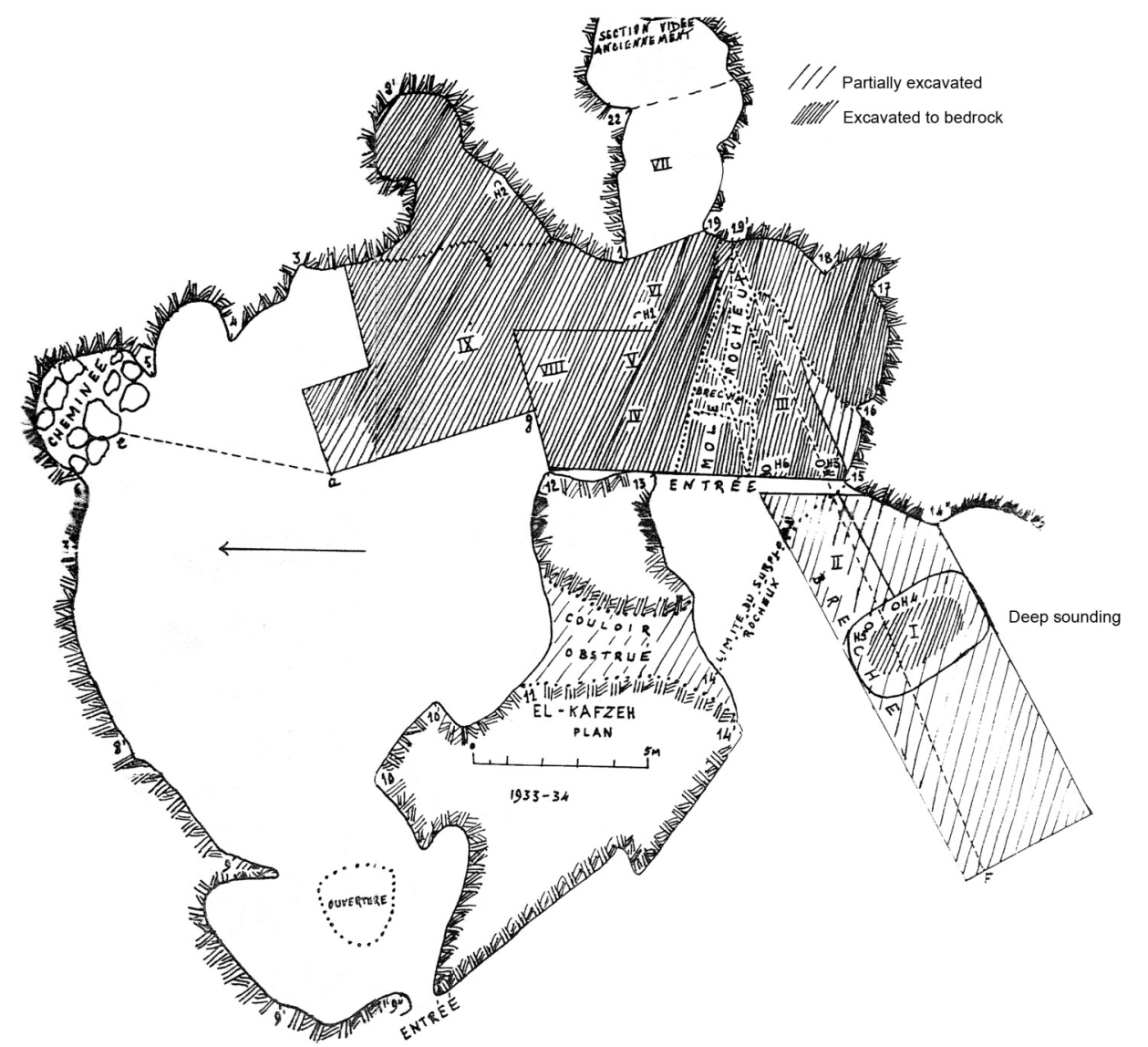

\section{FIGURE 2}

Map by R. Neuville and M. Stekelis indicating the excavated areas in 1933-34. (Qafzeh archives).

Plan de R. Neuville et M. Stekelis montrant les surfaces fouillées en 1933/1934

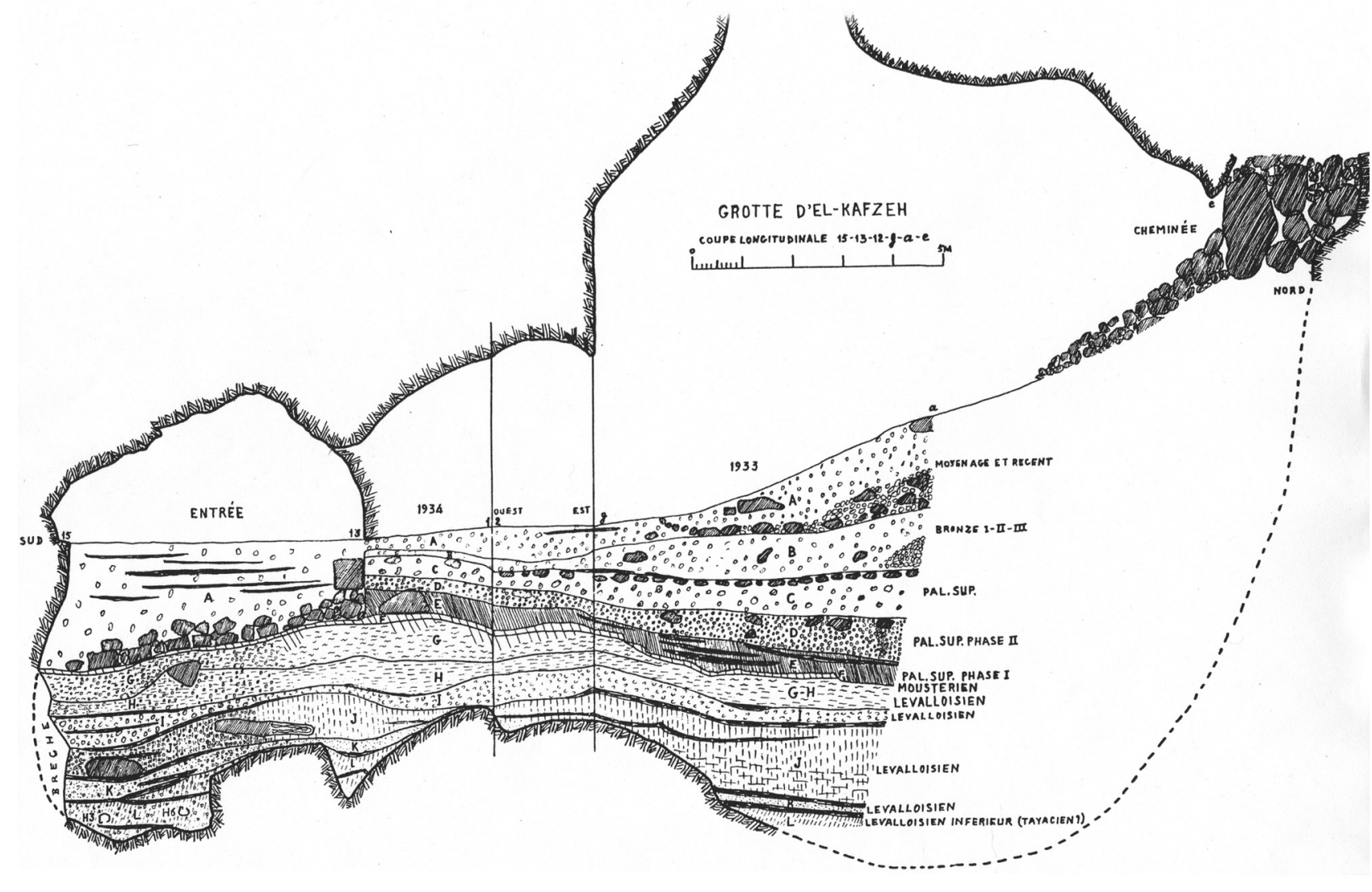

- FIGURE 3 -

Stratigraphic section of the Neuville/Stekelis excavations indicating the location Stratigraphie de Neuville/Stekelis avec la localization de Qafzeh 3 et Qafzeh 6. of Qafzeh 3 and 6 (Qafzeh archives). 


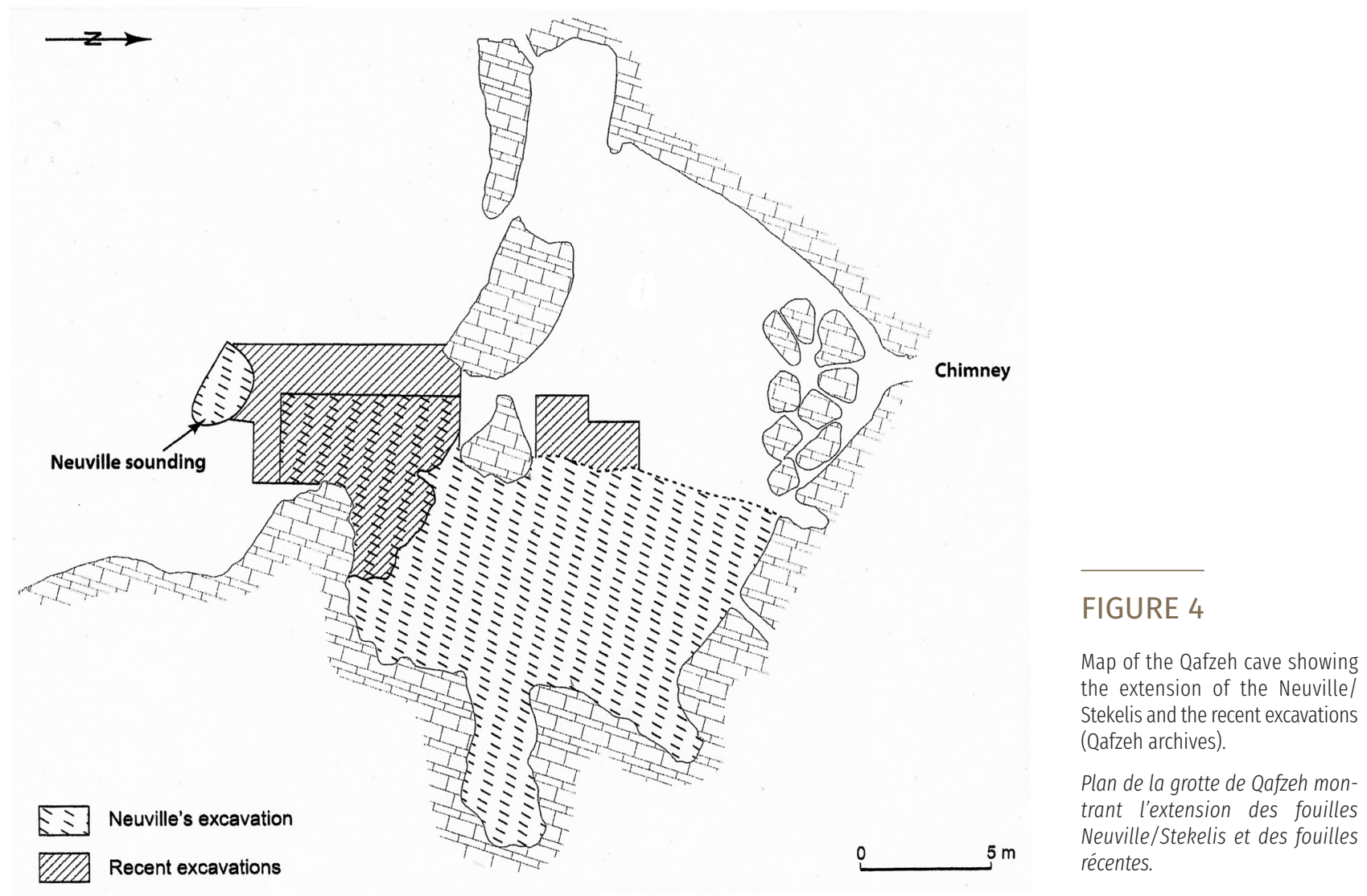

New excavations focusing on the Terrace with minor operations inside the cave, were initiated in 1965 under the direction of one of us (B. V.) based on a standard grid system. The original aim was to obtain further information on the human remains discovered by Neuville and Stekelis, as well as detailed information on stratigraphy, chronology and the nature of the lithic industries. The human remains discovered since 1965 had received the successive numbers from Q8 onwards (tabl. 1). In a visit to the cave M. Stekelis confirmed that the first new fossils $(\mathrm{Q} 8, \mathrm{Q9}, \mathrm{Q10})$ originate from the same deposit as Q3 to Q7 recovered previously.

Since the first season, new human remains were uncovered in the Middle Paleolithic layers XVII-XXII. The last excavation seasons took place in 1977-1979 when O. B.-Y. joined the team. Later, in 1996-1997, the site was cleaned at the request of the Nazareth municipality that wished to create a site museum. Unfortunately this plan fell through due to changes in the political atmosphere in Israel. This last operation allowed us to dig an additional Upper Paleolithic section inside the cave (Bar-Yosef and Belfer-Cohen 2004) dated to ca. 33-31ka cal BP.

\section{2 | STRATIGRAPHY}

The rocky sill that separated the cave chamber from the Terrace deposits was partially removed already in Byzantine times and later during the 1933-1935 excavations. Because of this separation between cave and terrace, in 1965 it was decided to use a different numbering system for the layers of each area. Thus Arabic numerals were employed for the stratigraphic observations inside the cave and Roman numerals for the Terrace.
Thirteen layers were identified inside the cave. Layers 1 to 3 were the latest deposits overlying a probable Byzantine pavement. Layers 4 to 9 were attributed to the Upper Paleolithic. Below them layers 10 and 11 contained impoverished Upper Paleolithic assemblages (Ronen and Vandermeersch 1972; Bar-Yosef and Belfer-Cohen 2004; Vandermeersch et al. 2013). Two thick layers (12 and 13) produced abundant Middle Paleolithic lithic artifacts but no faunal remains. These layers, which comprise the cave's Mousterian deposits, were highly disturbed during late Middle Paleolithic or early Upper Paleolithic times, when renewed karstic activity filled the lower part of the chamber with slow-flowing water that caused abrasion of all Middle Paleolithic lithics. The water dissolved the bones, leaving behind carbonates and phosphates deposited by evaporation on the terrace in the form of collophane (carbonate-rich apatite). These disturbances completely erased the original Mousterian stratigraphy inside the cave and caused a long hiatus between the Middle Paleolithic and the Upper Paleolithic occupations. The over flow from inside the cave towards the Terrace was probably also responsible for the removal of the earlier Upper Paleolithic layers. Additional damage was caused by the building activities during the Byzantine period mentioned above, extending into a side gallery of the main chamber.

The excavations on the Terrace recorded 26 layers as recognized during the excavations (I to XXVI; fig. 5). The deposits are composed of angular limestone gravels and silts from the mountain slope with anthropogenic contributions of lithics, ashes and animal bones. The upper part is highly brecciated to uneven depths of about 2-3m. The cementation process of these layers is indicated by the 


\begin{tabular}{|c|c|c|c|c|}
\hline Homo & Discovery & Portions preserved & $\begin{array}{l}\text { Stratigraphical } \\
\text { position }\end{array}$ & First references \\
\hline Qafzeh 1 & 1934 & $\begin{array}{l}\text { Frontal and fragments of the } \\
\text { nasal bones. Mixed layer, top } \\
\text { accumulation of the inner } \\
\text { chamber. }\end{array}$ & $\begin{array}{l}\text { Probably Upper } \\
\text { Paleolithic }\end{array}$ & $\begin{array}{l}\text { Vandermeersch et al. } \\
2013\end{array}$ \\
\hline Qafzeh 2 & 1934 & $\begin{array}{l}\text { Partial cranial vault with } \\
\text { fragments of the face and two } \\
\text { fragments of the jaw. }\end{array}$ & $\begin{array}{c}\text { Layer } 7 \mathrm{a}, \\
\text { Upper Paleolithic }\end{array}$ & $\begin{array}{l}\text { Vandermeersch et al. } \\
2013\end{array}$ \\
\hline Qafzeh 3 & $1934 / 1935$ & $\begin{array}{l}\text { Incomplete adult skull, teeth, } \\
\text { post-cranial elements. }\end{array}$ & Layer XVI & Vandermeersch 1981 \\
\hline Qafzeh 4 & 1934 & $\begin{array}{l}\text { In fact, under this label, the } \\
\text { mixed remains of three } \\
\text { individuals are represented. } \\
\text { Qafzeh 4: child represented by } \\
\text { a jaw and two broken maxillary } \\
\text { elements; Qafzeh } 4 a \text { : Ilium of } \\
\text { a child and additional } \\
\text { fragments that Tillier } 1999 \text { has } \\
\text { associated to Qafzeh } 21 \text {; } \\
\text { Qafzeh 4b: three permanent } \\
\text { teeth. }\end{array}$ & Layer XVII & Tillier 1999 \\
\hline Qafzeh 5 & 1934 & $\begin{array}{l}\text { Fragments of the skull and } \\
\text { teeth of one adult and some } \\
\text { phalanges }\end{array}$ & Layer XVII & Vandermeersch 1981 \\
\hline Qafzeh 6 & 1934 & $\begin{array}{l}\text { Skull and fragments of post- } \\
\text { cranial elements of one adult. }\end{array}$ & Layer XVII & $\begin{array}{l}\text { Vallois and } \\
\text { Vandermeersch } \\
1972\end{array}$ \\
\hline Qafzeh 7 & 1935 & $\begin{array}{l}\text { Fragments of one adult skull } \\
\text { including the face and } \\
\text { numerous post- cranial } \\
\text { elements. }\end{array}$ & Layer XVII & Vandermeersch 1981 \\
\hline Qafzeh 8 & $1965 / 1966$ & $\begin{array}{l}\text { Fragments of one adult jaw } \\
\text { and maxilla, as well as } \\
\text { fragments of post-cranial } \\
\text { elements. }\end{array}$ & Layer XVII & $\begin{array}{l}\text { Vandermeersch } \\
1966,1981\end{array}$ \\
\hline Qafzeh 9 & 1967 & $\begin{array}{l}\text { Complete skeleton of one } \\
\text { adult. }\end{array}$ & Layer XVII & $\begin{array}{l}\text { Vandermeersch 1969, } \\
1981\end{array}$ \\
\hline Qafzeh 10 & 1967 & Complete skeleton of a child. & Layer XVII & $\begin{array}{l}\text { Vandermeersch 1969; } \\
\text { Tillier, } 1999\end{array}$ \\
\hline Qafzeh 11 & 1969 & $\begin{array}{l}\text { Skull and the upper part of the } \\
\text { post-cranial skeleton of a } \\
\text { child. }\end{array}$ & Layer XXII & $\begin{array}{l}\text { Vandermeersch 1970; } \\
\text { Tillier, } 1999\end{array}$ \\
\hline Qafzeh 12 & 1969 & $\begin{array}{l}\text { Crushed and deformed skull of } \\
\text { a child, with the upper part of } \\
\text { the trunk and elements of one } \\
\text { upper limb. }\end{array}$ & Layer XVII & Tillier 1999 \\
\hline Qafzeh 13 & 1969 & $\begin{array}{l}\text { Crushed and incomplete skull } \\
\text { and few elements of the post- } \\
\text { cranial skeleton of a baby. }\end{array}$ & Layer XV & Tillier 1999 \\
\hline
\end{tabular}




\begin{tabular}{|c|c|c|c|c|}
\hline Homo & Discovery & Portions preserved & $\begin{array}{l}\text { Stratigraphical } \\
\text { position }\end{array}$ & First references \\
\hline Qafzeh 14 & 1973 & $\begin{array}{l}\text { Perinatal. Fragments of the } \\
\text { skull and } 6 \text { germs of } \\
\text { deciduous teeth. }\end{array}$ & Layer XVII & Tillier 1999 \\
\hline Qafzeh 15 & 1973 & $\begin{array}{l}\text { Skull and about half of the } \\
\text { upper part of the post-cranial } \\
\text { skeleton of a child. }\end{array}$ & Layer XVII & Tillier 1999 \\
\hline Qafzeh 16 & 1973 & Incisor tooth & Layer XVII & Unpublished \\
\hline Qafzeh 17 & 1973 & Incisor tooth & Layer XVII & Unpublished \\
\hline Qafzeh 18 & 1975 & Incisor tooth & Layer XVII & Tillier, 1999 \\
\hline Qafzeh 19 & 1978 & Premolar tooth & Layer XVII & Unpublished \\
\hline Qafzeh 20 & 1978 & $\begin{array}{l}\text { One canine and four incisors, } \\
\text { permanent. }\end{array}$ & Layer XVII & Unpublished \\
\hline Qafzeh 21 & 1979 & $\begin{array}{l}\text { Skull fragments and post- } \\
\text { cranial elements of a child. }\end{array}$ & Layer XVII & Tillier 1999 \\
\hline Qafzeh 22 & 1979 & Deciduous canine & Layer XVII & Tillier 1999 \\
\hline Qafzeh 23 & 1979 & Premolar tooth & Layer XVa & Tillier 1999 \\
\hline Qafzeh 24 & 1979 & Teeth roots? & Layer XXI & Unpublished \\
\hline Qafzeh 25 & 1979 & $\begin{array}{l}\text { Crushed skull and incomplete } \\
\text { post-skeletal elements of one } \\
\text { adult. }\end{array}$ & Layer XV & Schuch et al. 2017 \\
\hline Qafzeh 26 & 1996 & Fragment of a child's jaw. & Layer XXII & Unpublished \\
\hline Qafzeh 27 & 1996 & Permanent canine & Layer XXII & Unpublished \\
\hline
\end{tabular}

distribution of brecciated areas that correspond to the wetness caused by water flowing from inside the cave to the area beyond the sill during the cave's occupation. The results of these intermittent activities, mostly during the Mousterian occupations, resulted in even cementation or brecciation of the various layers. It means that in some localities the same layer was partially cemented, while next to it in a distance of a few centimeters, the same sediments remained loose. Therefore, the different patterns in Figure 5 represent changes in color, not in the nature of the deposit. Needless to mention that these changes over very short distances made the digging operation difficult. Once these observations were noticed we realized that what we considered as layer XVI is simply a brecciated part of layer XV.

An additional observation related to the post-depositional effects is that the places of the blackened sediments with manganese salts, also made it difficult to distinguish between several of the upper Mousterian layers in the Terrace. In addition, when the water flow from the chamber into the terrace became intensive it created a major tunnel through the deposits, sometimes with adjacent minor ones. This water activity reflects a downhill flow that occurred in the same direction as the main wadi course of today.

\section{3 | THE AGE AND CONTEXTS \\ OF THE QAFZEH BURIALS}

The general chronology was already the topic of several papers. The lower Terrace layers (XVII to XXIII) have been dated by Thermoluminescence $(T L)$ to a mean age of $92,000 \pm 5,000$ with a range of $82.4 \pm 7.7 \mathrm{Ka}$ to $109 \pm 9.9 \mathrm{Ka}$ (Valladas et al. 1988). Electron Spin Resonance (ESR) readings based on animal teeth produced two series of results for the range of layers XV through XXI: Early Uptake of $92 \mathrm{Ka}$ through $119 \mathrm{Ka}$ and Linear Uptake of $122 \mathrm{Ka}$ through 145Ka (Schwarcz et al. 1988). The suggested average was $115 \mathrm{Ka}$. Two recent studies also suggest to correlate Qafzeh with the MIS 5e (Frumkin and Comay 2019; Ambrose 2017). It is assumed that this average age suits the observed thickness of the lower layers and indicates that the deposits accumulated relatively rapidly.

Undoubtedly, this impression was formed using a Pleistocene scale. One would wonder what would be the time range or possibly a more accurate estimate if we had more precise dating techniques.

In the upper layers (IX-XV) the intensive occupation is reflected by the presence of a rich lithic assemblage and faunal remains, and the cementation process of sediments 


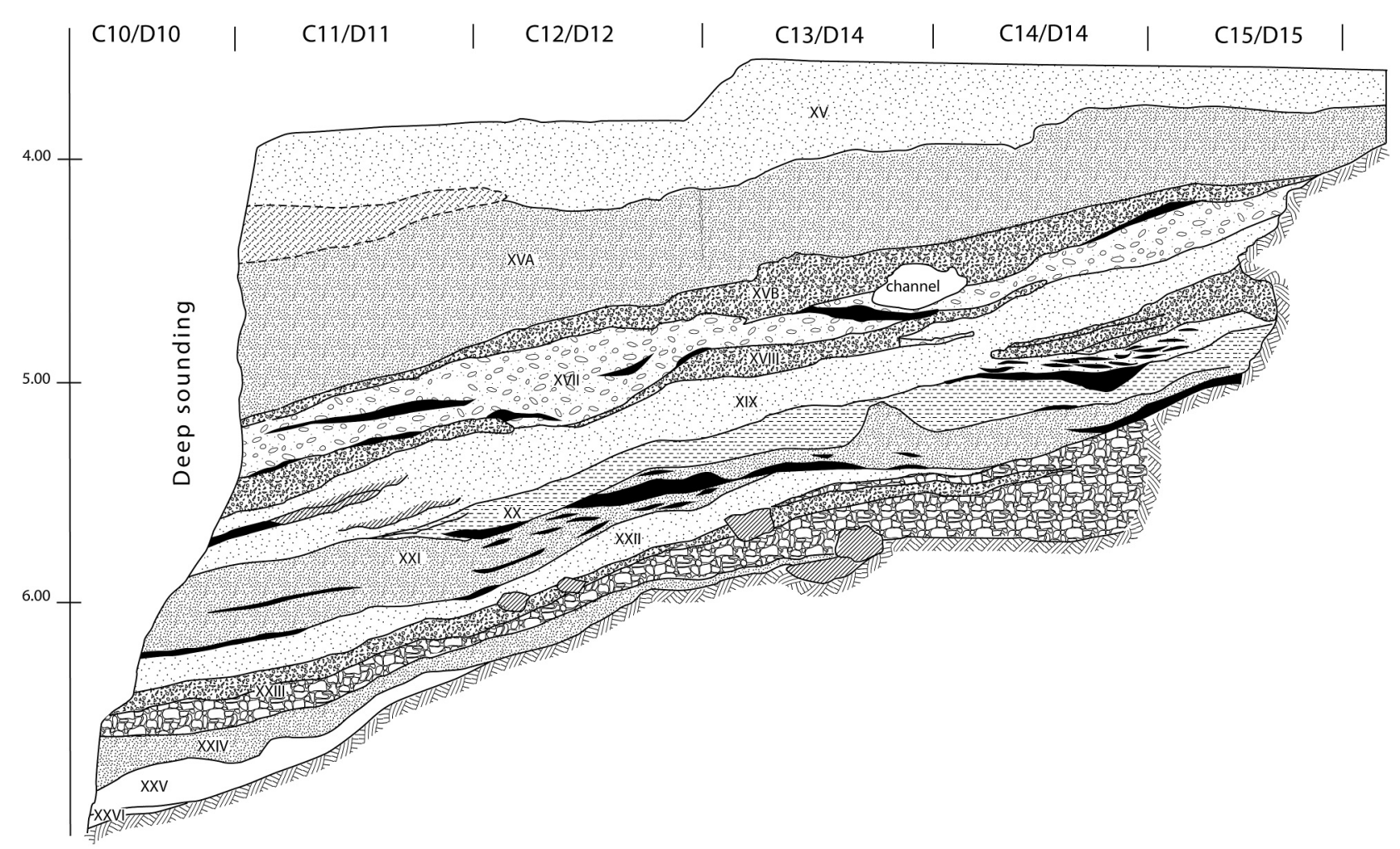

\section{- FIGURE 5 -}

Profile of the Terrace showing the Middle Paleolithic stratigraphy. The layers I to XIV were reduced and only present against the wall of the cave. They probably have been removed during the Byzantine period. (Qafzeh archives).

happened mostly in situ as a result of the karstic activity in the cave. Layers XVII to XXVI (fig.5), where most of the human fossils were found, were also cemented in several places. They were about 1.5 to $1.3 \mathrm{~m}$ thick, during which the cave was occupied less intensively as indicated by the frequency of the micro-vertebrates (Rabinovich and Tchernov, 1995; Rabinovich et al., 2004). The upper sequence contained special artifacts such as the incised flake (Hovers et al. 1997) and a lump of scraped red ochre (Vandermeersch 1969b; Hovers et al. 2003). The lower assemblage produced several Glycymeris sea shells in layers XXI - XXIV (Bar-Yosef Mayer et al. 2009).

Reservations about dating are in order also for the later accumulations because all efforts to date the later layers XV through I, failed. This is perhaps due to the effects of water activity inside the cave, which was also responsible for the brecciation of the uppermost sequence of the Terrace as described above. Diagenesis dissolved most of the Middle Paleolithic fauna inside the Cave chamber but not on the Terrace.

Indeed, almost all bones found in the Mousterian layers at Qafzeh, whether animal or human, originated from the excavations in the Terrace of the cave. The absence of Middle Paleolithic bones from the deposits inside the cave is due to the dissolution of the bones, associated with the abrasion of all lithic artifacts in this enclosed area. This is not an isolated phenomenon, resulting from the impact of slow flowing water inside caves, but a common activity
Stratigraphie du Palélithique moyen de la terrasse. Les couches I à XIV, très réduites, ne sont conservées que contre la paroi de la grotte. Elles ont probablement été détruites pendant l'occupation byzantine.

in karstic environments. The outcomes of this occurrence vary. Bones could be dissolved, stained by minerals, washed away and abraded by flowing water, or become consolidated by the formation and deposition of speleothems, and more. The excavations inside Qafzeh cave, both during the early series in 1933-35 and those after 1965 demonstrated that in the deeper and earlier (pre-Upper Paleolithic) part of the cave's interior no bones were preserved and that all lithics were slightly abraded. The effects of this indoor permanent 'pond' were long lasting. The water sometimes poured over the sill and flew in a channel or two through the deposits of the earlier layers. This was probably due to wetter conditions that continued to affect the process of brecciation and mineral solution. The effects are well recorded in the partial consolidation of layers XV, XVA and several patches in the earlier deposits. This phase of wetness inside the cave determines an important change in the overall depositional history of the inside chamber at Qafzeh, which affected also the outside Terrace depositions. Moreover, we note the formation of a tunnel that ran through the entire sequence originating near the sill where the outside layers started their spread outwards and continued through the excavated area on the terrace. Given the small diameter of the tunnel (ca. 30-35 cm) in the upper layers it spread the wetness and partial consolidation of the deposits unevenly, affecting sometimes the conservation of the fossils as mentioned here. 
Middle Paleolithic burials provide one of the few opportunities to investigate human behaviors that are not directly related to subsistence activities. Human burials and more generally, funerary practices - are not a biological necessity and thus correspond to a different kind of preoccupation that concerns the fate of individuals when they die (Vandermeersch 2006).

Funerary rites may inform us on the relationships between the living and the dead, and possibly during the afterlife, whether for a short or longer period of time. Preceding the appearance of engraved or painted rock art (Henshilwood et al. 2018), funerary practices offer one of the few opportunities to address the deepest elements of the psyche of Paleolithic humans.

The presence of human burials in Levantine Paleolithic sites is only a small portion of the available Old World data sets, but often it is taken as representing an important step in human behavior (e.g., Harold 1980; Gargett 1989,1999; Riel-Salvatore and Clark 2001; Pettitt 2011). Specifically, in each case burial is considered as related to the complex nature of the interpretation of the place of death in human society. The history of human burial excavations produced a very rich literature on this subject but in the present context we limit our discourse to a shorter list of aspects that require an in-depth discussion.

There have been several researches dedicated to the question of whether or not Middle Palaeolithic burials of either modern humans or Neanderthals were intentional (e.g., Gargett 1999; Rendu et al. 2014; Goldberg et al. 2017). In this paper we will attempt to demonstrate the intentionality of the burials using the following arguments: First, while describing evidence for intentional burials as those found in Qafzeh (nos. 9, 10, and 11), or in Skhul caves, we accept the basic notion of a priori intentionality in the act of digging a grave, placing the dead inside and covering it. Supporting evidence is provided by the antler placed in burial 11 , or by the incised flake near burial 8 , or by the object covered with scraped red ochre and, maybe also, the seashells in the lowermost layers. Apparently, there was a repeated use of the Terrace by humans involved in mortuary practices, who were also responsible for building a few fires, leaving behind a collection of lithics that, as demonstrated through detailed analysis, were technologically homogeneous and mostly produced on site (Hovers 2009).

Second, the list of questions related to the details observed through the excavation of graves has the potential of being very long, depending on the degree of preservation of the elements attributed to the grave and its furniture. Among the common and basic ones are the location of the burial in its immediate environment, evidence for neighboring graves, etc.

The earliest burials are thus considered an important source of information as regards prehistoric human existence because they may indicate different types of behavior that may or may not signal a major step in the social history of humanity (e.g., Binford 1968; Saxe 1970; Binford 1971; Tainter 1978; Belfer-Cohen and Hovers 1992; Hovers et al. 1995, 2000; Pettitt 2011; Hovers and BelferCohen 2013).
The contexts of the burials at Qafzeh, the main topic of this discussion, provide us with information concerning funerary practices in the Levant during a particular period. We do not intend here to get entangled with the controversies concerning the detailed chronology of the Levantine fossils traditionally identified as Neanderthals (e.g., Tabun C1, Amud and Dederiyeh) or early Modern humans (e.g., Tabun C2, Qafzeh, Skhul and Misliya) (McCown and Keith 1939; Vandermeersch 1969a, 1981; BarYosef and Callander 1999; Valladas et al. 1999; Mercier et Valladas 2003; Akazawa et al. 2004; Rak et al. 1994; Herskowitz et al. 2018).

Though the remains of more than 25 individuals have been recorded in the Terrace only a few of them were, according to the current interpretation, buried intentionally (fig.6). These reasonably well preserved burials are distributed within the excavated layers from XVII to XXIV. Although it seems that the archaeological layers in Qafzeh demonstrate a relatively rapid process of accumulation, the available radiometric dates do not permit an easy time estimate of the time passed between the top of XVII and the bottom of XXIV.

We suggest that the detailed presentation and commenting on the two best preserved burials (Qafzeh 9 and 10 and Qafzeh 11) will assist us in establishing the manner through which a most sound interpretation of the graves and their meaning can be achieved. We therefore see the detailed study of both inhumations as the first step in the analysis. The main advantage of these burials, compared to the others, is their degree of completeness. We adopt a similar approach to other complete graves, whether they are classified as Middle or Upper Paleolithic, thus contributing to a better understanding of how these funerary customs evolved in the past. However, at the same time we should not ignore the information we can derive from the partially preserved burials, e.g., when only a part of the skeleton is present.

\section{4 | THE MAIN QAFZEH BURIALS}

This section begins with a description of the joint burial of hominins 9 and 10 and goes on to discuss the single burial of 11. The latter was uncovered in an earlier deposit. It seems that the degree of preservation of the different graves is related more to the contexts of the grave than to its exact location.

\section{Qafzeh 9 and 10:}

A major discovery was made during the exactions in 1967 when a double burial was uncovered in the deposits of Layer XVII. To date, it is the only double inhumation known from the entire Middle Paleolithic record (Vandermeersch, 1969). It was oriented north-south and contained the skeletons of two individuals: an adult, Qafzeh 9, and a child, Qafzeh 10 (fig.7).

Qafzeh 9 has been deposited on its left side. The torso was slightly curved and the head inclined toward the front. The left arm was slightly bent and the hand was positioned under the left thigh. The right arm was very bent, with the hand lying on the left forearm. The legs were bent toward the body. Most of the bones were partially crushed, but it 


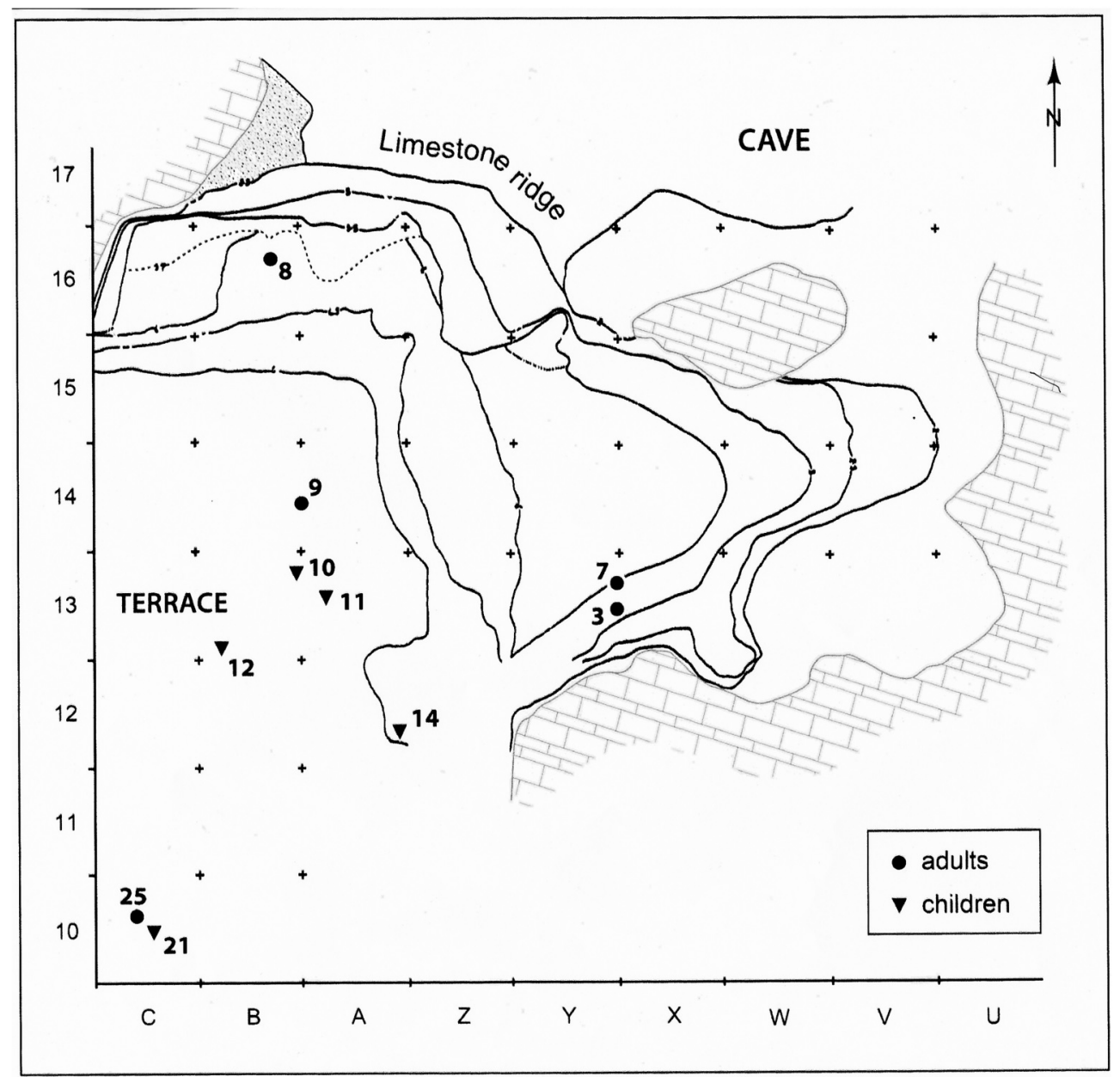

\section{FIGURE 6}

Map of the terrace indicating the location of the skeletons discussed in this paper. The location of the Neville's discoveries (3 et 7) is approximate due to the lack of precise data. (Qafzeh archives).

Plan de la terrasse avec la localisation des squelettes discutés dans cet article. La localisation des découvertes de Neuville ( 3 et 7 ) est approximative.

was possible to reconstruct the skull, mandible, clavicles and most of the limb bones. The preservation state of the torso and the pelvis facilitated their restoration.

The child's skeleton, Q10, was positioned perpendicularly to that of the adult, the head towards the east. The body was laid on its back, slightly inclined on its left side. The vertebral column formed a concave curve toward the top, especially accentuated at the cervical vertebrae, which were very high. The skull, turned to the left, was thus not horizontal with the torso, but positioned above it. It was in a forced flexed position, resting on its base. The right arm, lying a small distance from the torso, was slightly bent, the hand in line with the pelvis. The left hand was bent up to the left shoulder. The legs were turned to the left and very bent, the knees in line with the bottom of the rib cage. All these details provide the impression that the body was compressed to fit in within a small space.

During the excavation we did not detect an outline of a pit, which under the circumstances was expected, but this could be explained by reference to the history of the fill. The pit was inside layer XVII and then filled in with the sediments that were excavated when the burials were interred into the final position in order to cover the human remains. Therefore there was no difference in color between the compositions of the original sediments and the fill. Furthermore, indications of the limits of the pit would have been obliterated by the breccification and the black coloration of sediments and bones by manganese.
Nonetheless we believe that originally there was an excavated burial pit intended for the double burial. The following arguments support this assumption:

A.- Both skeletons were well preserved in anatomical connections and in a position that implies human intervention. This means that the bodies were intentionally protected from scavengers, even if only in a minimal way. If they had been simply deposited and abandoned where we found them, necrophagous carnivores would have been involved and the bones would be scattered, probably displaying tooth marks.

B.- Both skeletons occupied a perfectly elongated rectangular space. If we pass a straight line along the knees of the adult and the skull of the child, and another along the base of the pelvis of the adult and the extremity of the left hand of the child, we obtain two parallel lines. Such a configuration means that the two bodies were placed within a space of homogeneous width. Accordingly, it seems that the two lines correspond to the edges of a pit, which have since been obliterated by the breccification and manganese coloration.

C.- The posture of the young child requires an explanation. Its strongly bent position along the axis of its cervical spine and head demonstrates that his body was pushed against the wall of the pit. It seems that in the process of interment those in charge of the burial process wished to fit in the body in the available space that was equal to the width of the area occupied by the adult's body. Under 


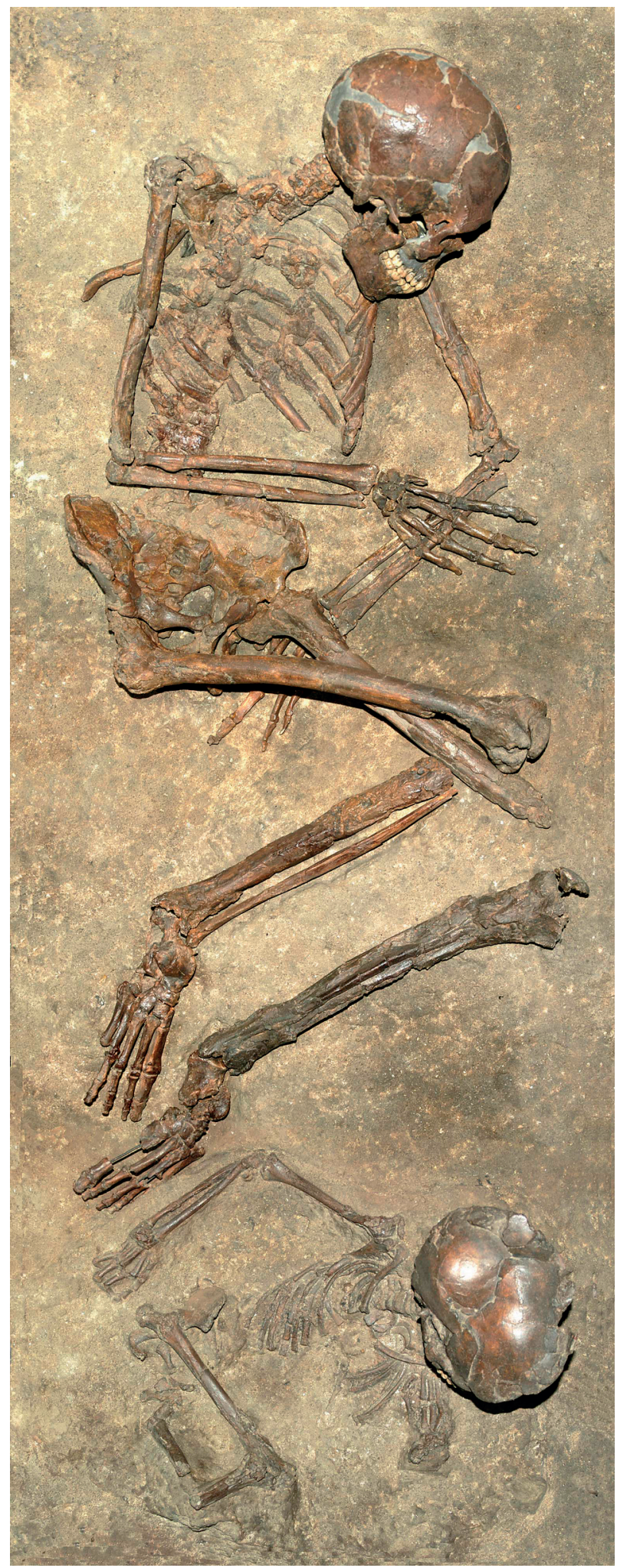

these circumstances, the body of the child became bent against itself. This probably implies that the burial was done shortly after death, before rigor mortis was complete.

D.- Both bodies were interred at the same time. The left arm of the child was parallel to the right foot of the adult, a few centimeters away and slightly above it. If the child had been buried after the adult, the foot bones of the latter would have been dispersed if the individual was already skeletonized. However, as reported, they were all in perfect anatomical position.

\section{FIGURE 7}

Reconstruction of the double burial of Qafzeh 9 and 10 (Qafzeh archives).

Reconstitution de la sépulture double de Qafzeh 9 et 10.

E.- Both skeletons were perfectly horizontal, while the archaeological layers in this area slope to a degree towards the wadi. Apparently, the 'pit' was excavated and prepared for its current position before the bodies were deposited.

All these details ensure the conclusion that this was an intentional, simultaneous, double burial of an adult and a child, so far a unique occurrence in the Middle Paleolithic. This double burial raises a few additional questions. For example: what was the relationship 
between the adult and the child? Could this have been a mother and her child? In order to answer this question we suggest that the gender of the adult was a young female. In particular, the pelvis demonstrates several female characteristics, e.g., the ischio-pubic index, the sciatic notch and the under-pubic angle (Vandermeersch 1981).

All of the cranial sutures of the adult are open and the pubic facet, well-preserved on the left, is consistent with stage 2 of the Brooks classification (Brooks 1955), which corresponds to an age of 20-21 for a modern human. In addition, some of the bone epiphyses are not completely fused (Vandermeersch 1981). This indicates a young adult female. According to Tillier (1999), the dental criteria indicate that the child was around 6 years old, an age that corresponds to the ossification stages of the cranial and postcranial bones. Given these age estimates we suppose that the double grave contained the bodies of a young mother and her child. The state of their teeth, as mentioned above, is an additional argument to support this contention. Unfortunately, the bones are highly mineralized and we assume they do not contain collagen that would enable DNA analysis.

The simultaneous burial of these two individuals in the same grave cannot be accidental. The two bodies were interred together and could have been a subject of a complex funerary practice. Both had probably died at the same time. But there is a contrast between the adult, whose body was carefully positioned in the tomb, and the child, who was bent and squeezed to fit into a narrow space. It is probably significant that the latter was placed at the feet of the adult, rather than at its side. We must recognize, however, that although we are able to partially reconstruct the sequence of the funerary practices, their full meaning escapes us.

\section{Qafzeh 11:}

The second burial was discovered in 1969, near the southern wall of the cave, in layer XXII within a deposit composed of abundant limestone fragments within a fine grayish ashy sediment. This location in layer XXII directly overlies the friable bedrock that slopes to the south, in the direction of the wadi. The rocky floor of this area consists of highly fragmented limestone, originally exposed during the geological movement of the fault line that also exposed the cave. We note that this deposit was also easy to dig by hand.

The skeleton (fig.8) was deposited in a roughly rectangular pit dug into the rocky bedrock. The pit, 50 to $60 \mathrm{~cm}$ wide and 25 to $30 \mathrm{~cm}$ deep, was oriented in a north-south direction. The length of the pit could not be determined since its southern part was very disturbed by flowing water, which also deposited the manganese salts that homogenized the color of the layer and the bedrock. The bottom half of the skeleton was thus present only in the
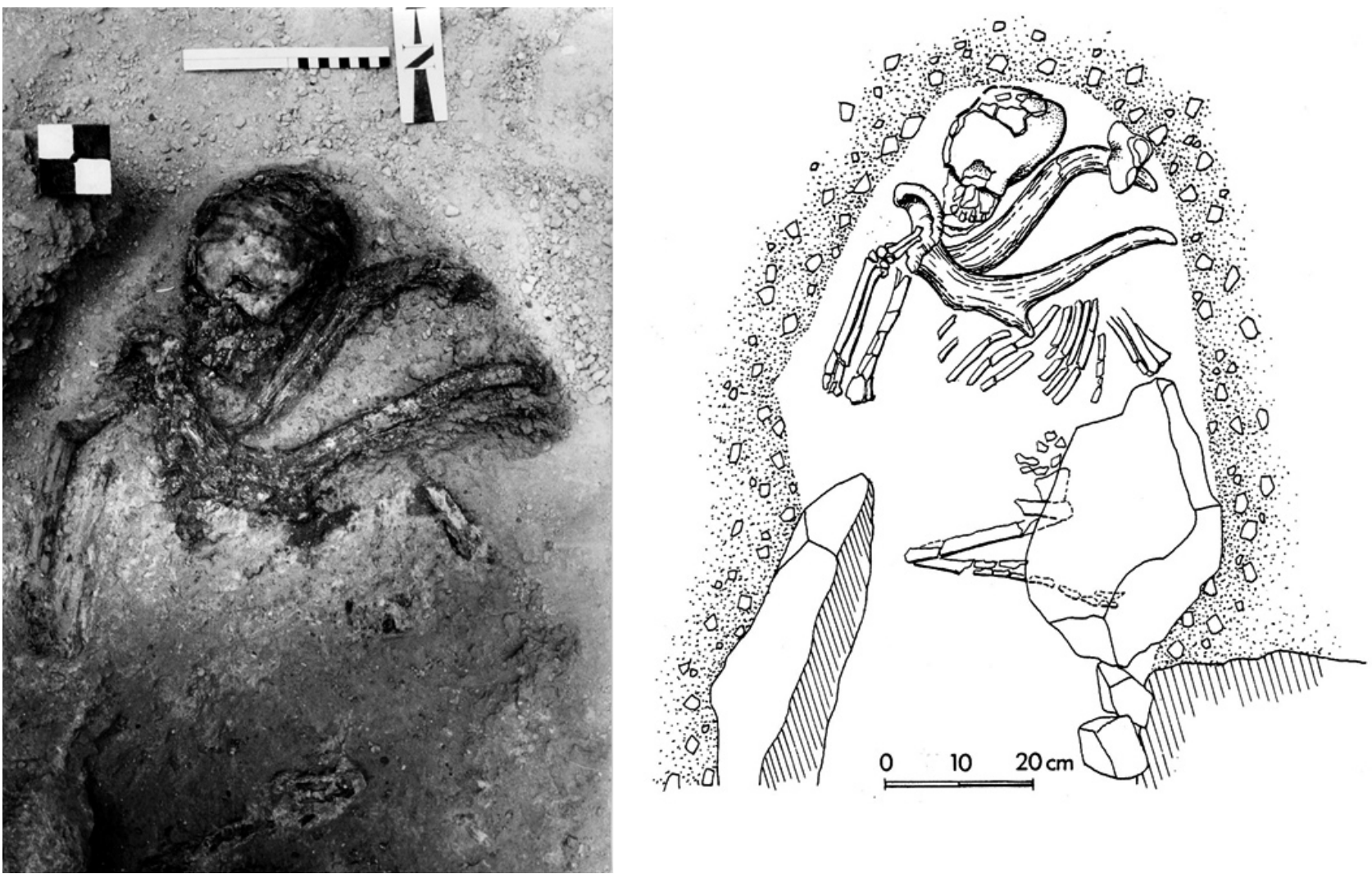

- FIGURE 8 -

Qafzeh 11 burial picture and drawing, not to the same scale (Qafzeh archives)

La sépulture de Qafzeh 11 (le dessin et la photographie ne sont pas à la même échelle). 
form of imprints, which nonetheless enabled us to identify the lower limbs. Fortunately, the sides of the pit and its northern extremity were clearly identifiable due to the contrast between the gray ashy fill and the whitish limestone of the rocky floor. In some places, larger limestone blocks, different in nature from those in layer XXII, were placed on their edges, perhaps to consolidate the walls of the pit. The depth of this pit in the bedrock, measured from the base of XXII, was ca. $25 \mathrm{~cm}$, thus apparently its original depth was greater when layer XXII was already at least partially deposited.

The pit contained the skeleton of a 12-13 year-old adolescent (Tillier 1999). The body was positioned on its back (fig. 8). The head was raised and supported against the wall of the pit in a forced flexed position against the thorax. The legs, folded against the body, were pushed to the right. The pelvis and legs were crushed by a large limestone block of a size very different from that of the usual small stones in layer XXII. The arms were bent, with the humeri along the thorax and the hands laying at each side of the neck with the palms turned upward. A piece of a hunted large deer (Dama dama), bearing a portion of its skull, was laid across the upper part of the thorax, just below the head. There was direct contact between the bones of the right hand of the individual and the broken forehead of the animal. This piece, unique in all of the Mousterian deposits excavated at Qafzeh, was intentionally placed across the corpse and is probably the clearest evidence for a Middle Paleolithic grave offering, although we prefer the more neutral term of "intentionally deposited".

A similar situation was noted in Skhul cave where a boar's mandible was placed on Skhul V, "in the angle formed by the left forearm and the right humerus" (McCown in: Garrod and Bate 1937, p. 100). An additional case was reported from Amud Cave where a deer mandible was directly placed on the pelvis of Amud 7 (Rak et al. 1994; Hovers et al. 1995, 2000).

The skull of this adolescent (Q11) is fractured on the right side of the frontal bone and the edges of the fracture display the stigmata of bone regeneration (Dastugue 1981). This severe injury did not result in death, or at least not immediately. A recent study (Coqueugniot et al. 2014) showed that this incident probably occurred a long time before the adolescent's death, causing stunted brain growth that resulted in irreparable psychomotor damage, and perhaps also affected his/her oral communication capacities.

The cause of this injury is unknown. It could have been an accident or an act of interpersonal violence. The location of the skull fracture, on the right side of the frontal bone, along with its oblique orientation from bottom to top, suggests a blow with a blunt object. However, this tentative hypothesis is not supported by additional information. Moreover, one may wonder if there is a direct link between the injury this juvenile suffered and the decision concerning its intentional burial.

\section{5 | THE EARLY DISCOVERIES: QAFZEH 3 AND QAFZEH 7}

The first identified Middle Paleolithic burial was designated as Qafzeh 3 because the two skulls attributed to the Upper Paleolithic (Vandermeersch et al. 2013) had already been numbered as Q1 and Q2.

Of all the fossils found by Neuville and Stekelis (1933-1935), Qafzeh 3 is the only one represented by all parts of the skeleton (fig.9), except for the pelvis. Though we cannot be certain, it is unlikely that a body could be preserved in anatomical position without protection. The apparent lack of well-documented burials of the four other fossils discovered in 1933-1935, although a good number of skeletal elements were found, is probably due to the excavation techniques employed in those days. In any case, Qafzeh 3 is the only skeleton found by Neuville and Stekelis for which we have sufficient indications of a probable intentional burial.

\section{Qafzeh 7:}

Unfortunately we have only minimal information concerning the discovery of this individual, but Neuville's photo shows the anterior part of the vault with the face and the maxillaries articulated with the mandible (fig.10). In a short description of the human remains, without date but probably from 1934, Neuville wrote that there are the "two fragments of shoulder girdle and a few phalanges" as well as "a series of long bones that sunk into the sediment and can be studied as parts of this burial". Today, the skeletal remains stored in the Institute of Human Paleontology in Paris, include a part of the vault, the incomplete maxillaries, the incomplete mandible, the right forearm, a few bones of the right hand and parts of two calf bones. In our view the articulated position of the mandible with the skull and the presence of bones from the upper and lower limbs suggest that the entire body was protected, possibly buried. Unfortunately, no additional information is available to fully demonstrate that this was an intentional burial.

\section{6 | OTHER BURIALS: QAFZEH 8, QAFZEH 15 AND QAFZEH 25:}

The remains of Qafzeh 8 (fig. 11), discovered in 1965 in layer XVII (Vandermeersch 1966) were exposed at the end of the excavation season and a large portion was trapped under more than $2 \mathrm{~m}$. of extremely hard brecciated layers that were impossible to excavate rapidly. On the other hand, it was impossible to leave the already exposed upper part of the skeleton in place for the following season, given the site's public accessibility. The skeleton was thus excavated in the course of two seasons.

The body was oriented east-west, the head towards the east. No pit was detectable during the excavation, but in this part of the Terrace the layers are brecciated and uniformly colored black by manganese. In addition, the skeleton was located in the course of one of the water 

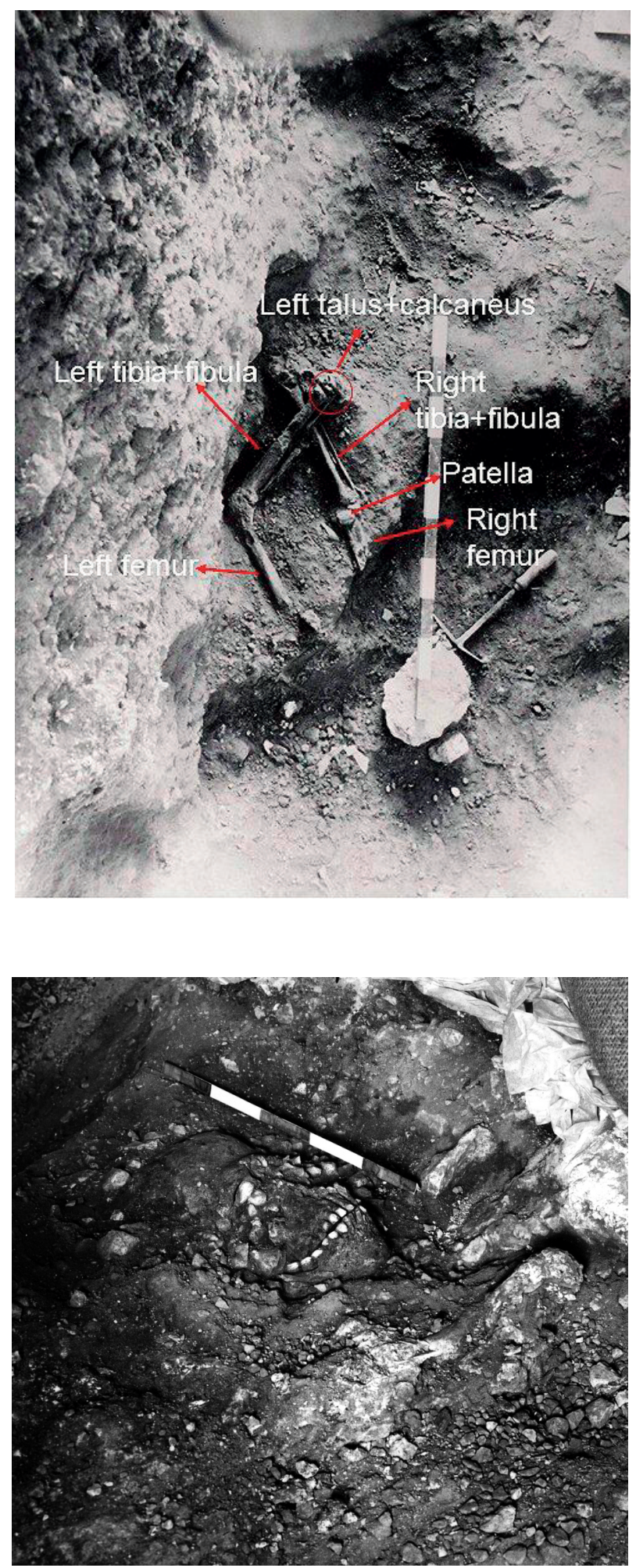

channels that flowed from the inside chamber causing major destruction to it. Only a part of the right maxilla with five teeth and the right mandible with three teeth survived in articulation. Of the pelvis, only a fragment of the right ischium was preserved. Both upper and lower limbs were less affected by the stream and the preserved parts were still in anatomical articulation.

\section{FIGURE 9}

Qafzeh 3: legs in place (photo R.Neuville, 1933).

Qafzeh 3 : les membres inférieurs en place.

\section{FIGURE 10}

Qafzeh 7 : skull in place (photo R. Neuville, 1933).

Qafzeh 7: le crâne en place.

The general position of the body could be observed. It was lying on its right side, the head strongly inclined toward the sector corresponding to the torso, the arms extended and the legs bent. A large limestone slab, compared to the usual small limestone pieces in layer XVII, covered the feet (fig. 11 no 65). Although it may look like part of the grave, it could be an accidental fall from the side wall. 


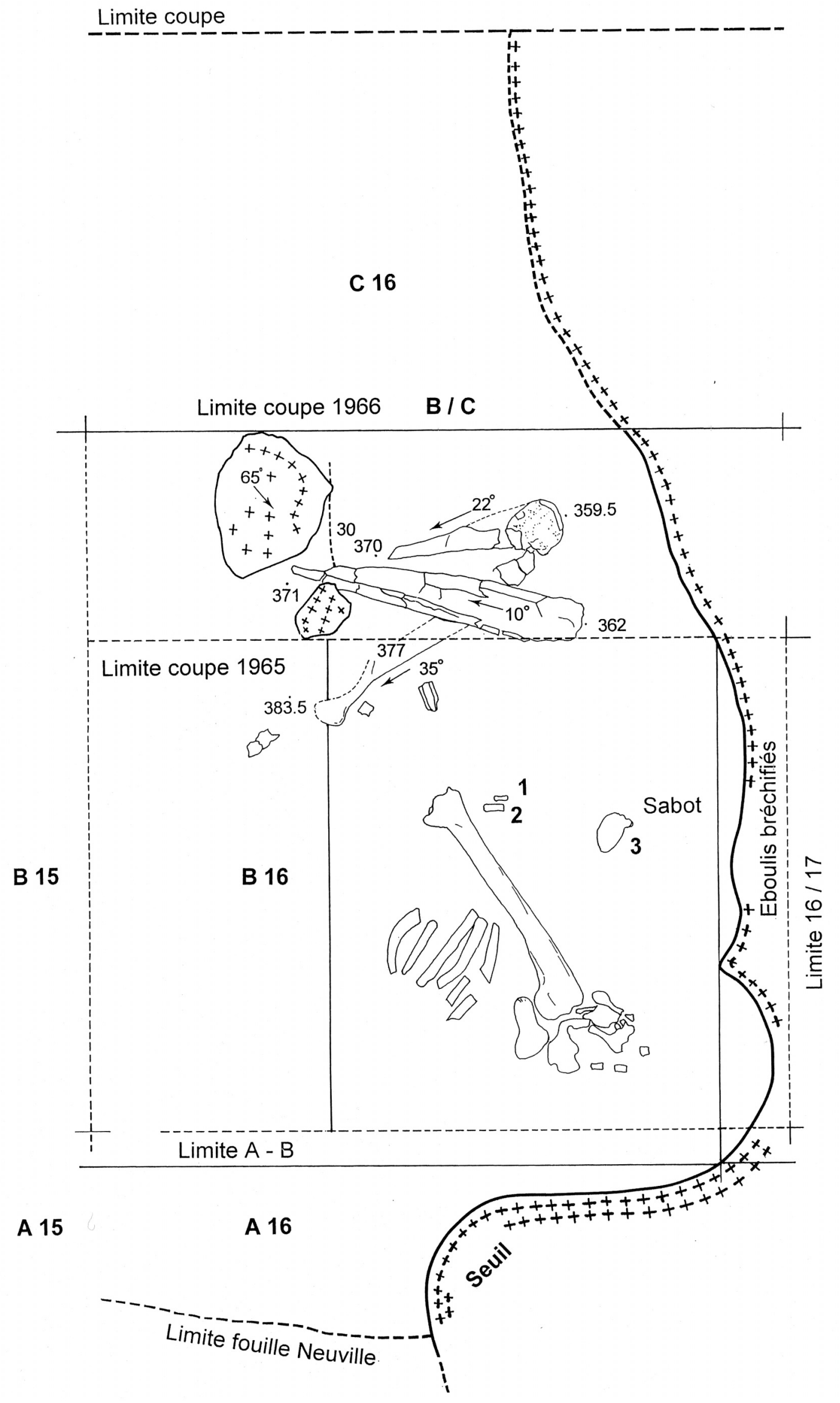

- FIGURE $11-$ 
In sum, the skeleton of Qafzeh 8 was initially complete, but was later partially destroyed by water during the final phase of the deposition of the Mousterian sequence. Was this really an intentional burial? Certain elements argue in favor of this interpretation. The preserved parts of the skeleton were in anatomical connection indicating that originally the skeleton was complete. Additionally, the entire assemblage occupied a space slightly greater than $1 \mathrm{~m} \times 0.80 \mathrm{~m}$, corresponding to a concavity in the cave wall, forming a sort of niche and suggesting that the corpse was laid so as to be protected from predators.

\section{Oafzeh 15:}

Another possible burial is that of Qafzeh 15 (fig. 12), also found in layer XVII. According to Tillier (1999), the age of this young child was approximately between three and four years.

The body was laid on its back, the head steeply inclined toward the thorax, the arms alongside the body. The upper half of the skeleton was in anatomical orientation, with the mandible articulated to the skull, while the lower half, below the rib cage, was totally absent (fig. 12). Other than this upper half, we found no bone fragments that could be attributed to this skeleton. We know of no other case of this type of partial preservation in the Paleolithic. The preservation of the upper parts of the skeleton and the disappearance of the lower part probably can be explained by the diagenesis of layer XVII at the end of the Mousterian. A similar case was noted at Kebara cave where about half of the femur of Kebara H2 disappeared due to active destruction by diagenesis. That this was the process in Kebara was shown by the systematic mineralogical analysis, a technique that was not available in the 1960's and 1970's (Weiner et al. 2007:143).

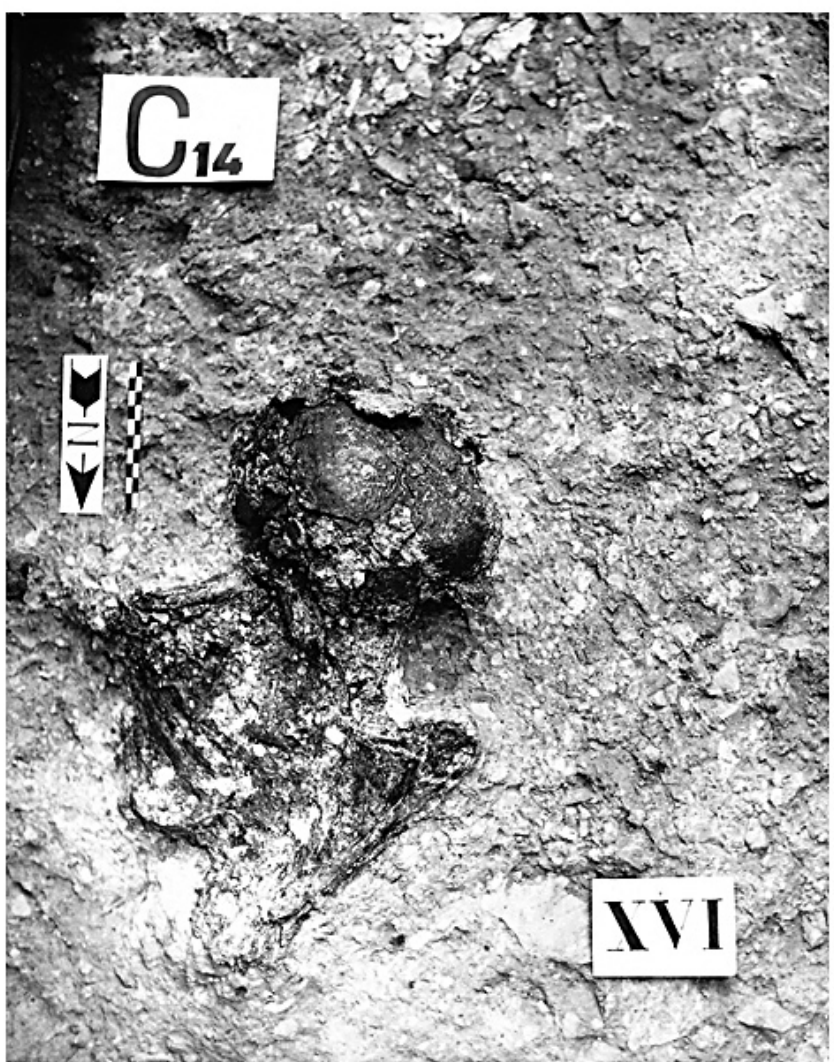

In Qafzeh, the layers in this sector of the site were brecciated and blackened by water percolation and the deposition of manganese. The disappearance of the lower half of the skeleton of Qafzeh 15 was apparently due to intensive, localized dissolution activity. Inside the cave chamber, as noted above, we have seen that water activity had devastating effects on the bones which had completely disappeared, while the artifacts were slightly abraded.

The hypothesis that this is an intentional burial is therefore based on the preservation of the upper half of this child's body in anatomical articulation, whose head could not have remained strongly inclined toward the thorax unless its occipital region was supported against an "obstacle" that maintained it in this position, perhaps the wall of a pit.

\section{Qafzeh 25:}

In 1979, while establishing the stratigraphic connection between our excavations and the large deep sounding of Neuville, we discovered a complete, but very crushed, skull with the mandible in place.

It was embedded in consolidated sediments while the bones of the cranial vault and the face were flattened and deformed to the point that they could not be easily reconstructed. Along with the skull, a small part of the upper half of the torso was found; it was also very crushed and a major portion was present only in the form of imprints (fig. 13). The rest of the skeleton must have been located in the northern part of the large sounding excavated in 1934, but being highly fragmented and altered, it was not recognized by Neuville and Stekelis. The anatomical articulation of the bones is once again the only indication of an intentional burial.

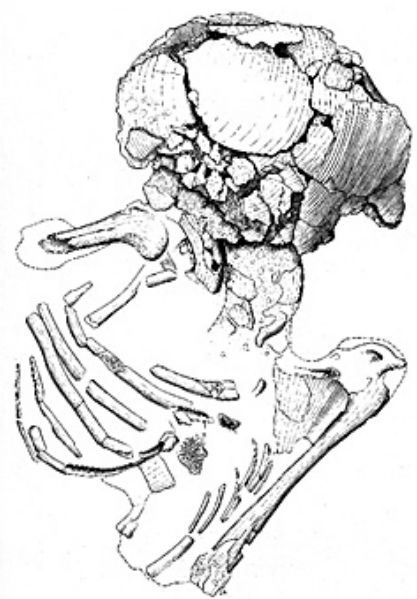

\section{FIGURE 12}

Qafzeh 15: picture and drawing of the preserved part of the skeleton (Qafzeh archives).

Qafzeh 15 : photographie et dessin de la partie conservée du squelette. 


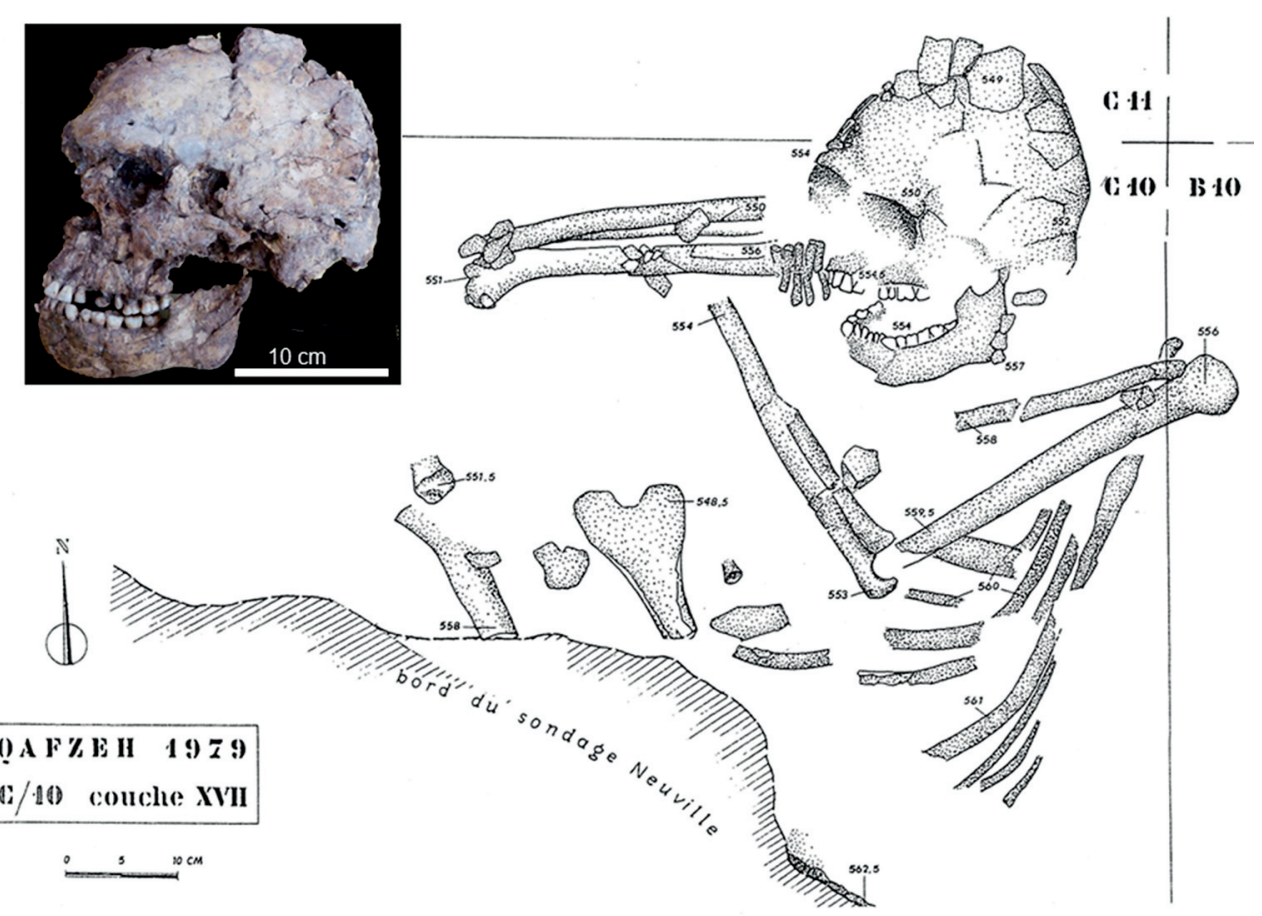

\section{FIGURE 13}

Drawing of the Qafzeh 25 skeleton in place and picture of the skull (Qafzeh archives).

Qafzeh 25 : relevé du squelette en place et photographie du crâne.
Finally, for the skeletal remains of very young or perinatal children, none of our field observations provided sufficient evidence to indicate intentional burials. These include several partial skeletons of children represented by only a few bone fragments. For example, Qafzeh 14, a child around 6 months old (Tillier 1999), is recognized by only a few teeth and cranial fragments dispersed in a fireplace in layer XVII. On the other hand, there is an approximately 3-year-old child, Qafzeh 21, (Tillier 1999), with remains of all parts of its skeleton clustered in a small space in layer XVII, yet they did not display anatomical connections. In spite of this, it seems that this body was somehow protected from predators. It is unlikely that such a large portion of a fragile skeleton could be preserved if the body, or the skeleton itself, was not intentionally protected. However, in such a situation we cannot confirm that the remains represent a definite "burial", portraying a set of social behavioral markers implied by this term.

\section{7 | DISCUSSION AND CONCLUSIONS}

The human bones discovered in Qafzeh cave seem to belong to a closely related single group of foragers. Unfortunately, the available dates can hardly resolve the issue of the length of time in which the place served as a cemetery. The stratigraphic and spatial proximity of the skeletal remains in an area of ca. $25 \mathrm{~m}^{2}$ over 1.5 meters of deposits may indicate a local group tradition. Moreover, many of the individuals (Q4,Q9, Q10, Q11, Q15 and Q25) demonstrate somewhat distorted position of one (but not the same one) of their teeth (Schuh et al. 2017) that seems to indicate a common biological heritage (Rougier et al. 2006 for the lower third premolar of the Krapina collection). We suggest that in spite of the poor state of preservation of the other Qafzeh fossils they also shared similar traits with those whose graves generally remained intact and full stop.
The cluster of the Qafzeh fossils can be interpreted in different ways, especially since they are present in a wide array of configurations, ranging from isolated remains that do not seem to have been treated in any particular manner, to irrefutable intentional burials and all of the intermediate possible combinations. Between the extreme two cases, described above, and the less well-preserved skeletons whose constituents are in anatomical connection, there is a variety of different degrees of preservation. This implies that a least a major portion of the human bodies was probably protected from predators and that at least some were fully buried. Assuming that intentional burials were also linked to some social rules means that we accept the record of well-preserved burials as fully or partially carrying the same symbolic 'baggage' that we would assign to Upper Paleolithic and even later graves. Still, this topic of burials and their symbolic-cumspiritual meaning requires further examination of the nature and contexts of the Qafzeh Middle Paleolithic funerary remains.

The current situation indicates that we have to recognize the two well organized graves that contain two individuals (nos 9 and 10) as the best example for practicing an intentional burial regardless of its potential interpretation. Accepting this observation serves us as a starting point in offering several interpretations to the other Qafzeh graves. To the indisputable double burials of Qafzeh 9 and 10 we first add the burial of Qafzeh 11. The two graves did not originate from the same layer and belong to two different phases whereby the earlier one (that of Qafzeh 11), characterized by the nearby presence of sea shells, is also separated from the later by about ca. $20 \mathrm{~cm}$ of deposits lacking human remains that are rich in microfaunal remains. This indicates that the funerary practices of the inhabitants of the site had persisted throughout a long span of time while the makers of local Mousterian industry were present and active. Based on the state of 
preservation of the exposed human remains, we suggest that only some individuals, often adults rather than children, were intentionally buried.

In addition, we wonder whether the deposit that accompanied Qafzeh 11 was linked to the pathological condition of this adolescent since it is the only observed case. When we summarize all our observations we feel that perhaps we will never be certain about the meaning of the observed funerary practices. Thus while we are certain that the Mousterians at Qafzeh provided special treatment to several of their dead, we do not know why.

On a global perspective, the small number of discovered Mousterian burials, whether of modern humans or Neandertals, shows that behaviors linked to inhumations were not the rule concerning the dead, but the exception. Maureille and Vandermeersch (2007) calculated that the total number of identified or suspected Middle Paleolithic burials of Neanderthals and anatomically modern humans combined amounts to between 40 and 45 individuals. This is a very small number relatively to the hundreds of fragmentary remains of individuals that have been identified in the course of excavations. Nevertheless, the preserved burials demonstrate that during the Middle Paleolithic funerary practices in several cases were similar to those of our own. This observation raises the question of 'why' and 'how' we have more than one kind of "state of preservation" in our records and an in-depth, widerange inquiry, is undoubtedly needed. Possibly future excavation will uncover additional skeletons and would provide good background for reassessing Middle Paleolithic burials.

\section{ACKNOWLEDGMENTS}

We would like to thank Erella Hovers and Anna BelferCohen (The Hebrew University of Jerusalem) for their comments on previous versions of this manuscript. We thank Daniella E. Bar-Yosef Mayer (Tel Aviv University) and María Dolores Garralda (Complutense University, Madrid) for editorial assistance, and Svetlana Matskevich for illustrations. The excavations at Qafzeh Cave were carried out with the permission of the Israel Antiquity Authority. It was supported by the CNRS and the Ministère Français des Affaires Étrangères. We thank the Centre de Recherche Français de Jérusalem, The Hebrew University of Jerusalem, Tel-Aviv University and The University of Bordeaux for providing assistance at different times. We thank all the students and our colleagues who took part in the excavations (1965 -1979), and in the study of this site.

\section{REFERENCES}

AKAZAWA T., MUHESEN S., DODO Y., KONDO O., YONEDA M. GRIGGO C., ISHIDA H. 2004 - Neanderthal burials: excavations of the Dederiyeh cave, Syria. In: Aurenche, O., Le Mière, M., Sanlaville, P. (Eds.), From the River to the Sea: The Palaeolithic and the Neolithic on the Euphrates and in the Northern Levant. Archaeopress, BAR S1263, Oxford, p. 241-270.
AMBROSE S.H. 2017 - Chronological calibration of Late Pleistocene Modern Human dispersals, climate change and Archaeology with Geochemical Isochrons. In: Y. Sahle, H. Reyes-Centeno, C. Bentz (Eds.), Modern Human Origins and Dispersal. Kerns Verlag: Tübingen. p. 171-213.

BAR-YOSEF O., BELFER-COHEN A. 2004 - The Qafzeh Upper Paleolithic assemblages: 70 years later. Eurasian Prehistory, 2, p. 145-180.

BAR-YOSEF O., CALLANDER J. 1999 - The women from Tabun: Garrod's doubts in historical perspective. Journal of Human Evolution, 37, p. 879-885.

BAR-YOSEF MAYER D. E., VANDERMEERSCH B., BAR-YOSEF O. 2009 - Shells and ochre in Middle Paleolithic Qafzeh Cave, Israel: indications for modern behavior. Journal of Human Evolution, 56, p. 307-314.

BELFER-COHEN A., HOVERS E. 1992 - Burial is in the Eye of the Beholder: Middle Palaeolithic and Natufian Burials in the Levant. Current Anthropology, 33, p. 463-471.

BINFORD S. R. 1968 - Early Upper Pleistocene adaptations in the Levant. American Anthropologist. 70(4), p. 707-717.

BINFORD L. R. 1971 - Mortuary practices: Their study and potential. In: J.A. Brown (Ed.), Approaches to the Social Dimensions of Mortuary Practices. Society for American Archaeology, 25, Washington, p. 6-29.

BROOKS S.T. 1955 - Skeletal age at death: the reliability of cranial and pubic age indicators. Am. J. Phys. Anthropol., $13, N^{\circ} 4$, p. 567-590.

COQUEUGNIOT H., DUTOUR O., ARENSBURG B., DUDAY H., VANDERMEERSCH B., TILLIER A.-m. 2014 - Earliest CranioEncephalic Trauma from the Levantine Middle Palaeolithic: 3D Reappraisal Brain Damage on Individual Life Condition and Social Care. PLOS ONE, Vol. 9, Issue 7, e102822.

DASTUGUE J. 1981 - Pièces pathologiques de la « nécropole » moustérienne de Qafzeh. Paléorient, 7, 1, p. 135-140.

FRUMKIN A. \& COMAY O. 2019 - The last glacial cycle of the southern levant: Paleoenvironment and chronology of modern humans. Journal of Human Evolution, doi:10.1016/j.jhevol.2019.04.007.

GARGETT R.H. 1989 - Grave shortcomings. Current Anthropology, 30, 157-191.

GARGETT R.H. 1999 - Middle Palaeolithic burial is not a dead issue: The view from Qafzeh, Saint-Césaire, Kebara, Amud, and Dederiyeh. Journal of Human Evolution, 37(1), 27-90. doi:10.1006/jhev.1999.0301

GARROD D.A.E., BATE D.M.A.1937 - The Stone Age of Mount Carmel I: excavations at the Wadi-el-Mughara. Oxford: Clarendon Press, 240 p.

GOLDBERG P., ALDEIASI V., DIBBLE H., MCPHERRON S., SANDGATHE D. \& TURQ A. 2017 - Testing the Roc de Marsal Neandertal "Burial" with geoarchaeology. Archaeological and Anthropological Sciences, 9(6), p. 1005-1015. doi:10.1007/s12520-013-0163-2. 
HAAS G. 1972 - The microfauna of Djebel Qafzeh Cave. Palaeovertebrata, 5, p. 261-270.

HARROLD F. B.1980 - A comparative analysis of Eurasian Palaeolithic burals. World Archaeology, 12(2), p. 195-11. doi:10.1080/00438243.1980.9979792

HENSHILWOOD C.S., D'ERRICO F., VAN NIEKERK K.L., DAYET L., QUEFFELEC A., POLLAROLO L. 2018 - An abstract drawing from the 73,000-year-old levels at Blombos Cave, South Africa. Nature, doi.org/10.1038/s41586-018-0514-3

HERSHKOVITZ I., WEBER G.W., QUAM R, WEINSTEIN-EVRON M. et al. 2018 - The earliest modern human outside Africa. Science 359, p. 456-459.

HOVERS E. 2009 - The Lithic Assemblages of Qafzeh Cave. Oxford: Oxford University Press, 320 p.

HOVERS E., BELFER-COHEN A. 2013 - Insights into Early Mortuary practices of Homo. In: S. Tarlow, L. Nilsson Stutz (Eds.), The Oxford Handbook of the Archaeology of Death and Burial. Oxford: Oxford University Press, p. 631-642.

HOVERS E., KIMBEL W.H., RAK Y. 2000 - The Amud 7 skeleton - still a burial. Response to Gargett. Journal of Human Evolution, 39, p. 253-260.

HOVERS E., VANDERMEERSCH B., BAR-YOSEF O. 1997 A Middle Palaeolithic engraved artefact from Qafzeh Cave, Israel. Rock Art Research, 14, p. 79-87.

HOVERS E., ILLANI S., BAR-YOSEF O., VANDERMEERSCH B. 2003 - An Early Case of Color Symbolism: The use of ochre by early modern Humans in Qafzeh Cave. Current Anthropology, 44(4), p. 491-522.

HOVERS E., RAK Y., LAVI R., KIMBEL W.H. 1995 - Hominid remains from Amud Cave in the context of the Levantine Middle Paleolithic. Paléorient, 21(2), p. 47-62.

HOWELL F.C. 1958 - Upper Pleistocene men of the Southwest Asian Mousterian. In: G.H.R. von Koenigswald (Ed.), Hundert Jahre Neanderthaler. Köln-Graz, BöhlauVerlag, p. 185-198.

HOWELL F.C. 1959 - Upper Pleistocene Stratigraphy and Early Man in Levant. Proceedings of the American Philosophical Society, 103, p. 1-65.

KING W. B. R. 1864 - The reputed fossil man of the Neanderthal. Quarterly Journal of Science, 1, p. 88-97.

MAUREILLE B., VANDERMEERSCH B. 2007 - Les sépultures néandertaliennes. In : B. Vandermeersch, B. Maureille (Eds.), Les Néandertaliens. Biologie et Cultures. Paris: CTHS, p. 311-322.

McCOWN T., KEITH A. 1939 - The Stone Age of Mount Carmel.: The fossil human remains from the Levalloiso-Mousterian. Oxford: Clarendon, Vol 2, 390 p.

MEIGNEN L., BAR-YOSEF O. 1992 - Middle Paleolithic Variability in Kebara Cave, Mount Carmel, Israel. In: T. Akazawa, K. Aoki, T. Kimura (Eds.), The Evolution and Dispersal of Modern Humans in Asia. Tokyo, Hokusen-Sha, p. 129-148.
NEUVILLE R. 1934 - Le Préhistorique de Palestine. Revue Biblique, 43, p. 237-259.

NEUVILLE R. 1951 - Le Paléolithique et le Mésolithique du désert de Judée. Arch. de l'Inst. de Paléont. Hum. Paris, Masson, $270 \mathrm{p}$.

PETTITT P. B. 2011 - The Palaeolithic Origins of Human Burial. London: Routledge, 307 p.

RABINOVICH., TCHERNOV E. 1995 - Chronological, paleoecological and taphonomical aspects of the Middle Paleolithic site of Qafzeh, Israel. In: H. Buitenhuis, H.P. Uerpman (Eds.), Archaeozoology of the Near East II. Backhuys, Kerkwerve, Netherlands, p. 5-44.

RABINOVICH R., BAR-YOSEF O., VANDERMEERSCH B., HORWITZ L.K. 2004 - Hominid-Carnivore interactions in the Paleolithic site of Qafzeh cave, Israel. Genève. Revue de Paléobiologie, 23, p. 627-637.

RAK Y., KIMBEL W.H., HOVERS E. 1994 - A Neandertal infant from Amud cave. Journal of Human Evolution, 26, p. 313-324.

RENDU W., BEAUVAL C., CREVECOEUR I., BAYLE P., BALZEAU A., BISMUTH T., BOURGIGNON L., DELFOUR G., FAIVRE J.-P., LACRAMPE-CUYAUBĖRE F., TAVORMINA C., TODISCO D., TURQ A., MAUREILLE B. 2014 - Evidence supporting an intentional Neandertal burial at La Chapelle-aux-Saints. Proceedings of the National Academy of Sciences of the United States of America, 111(1), p. 81-86. doi:10.1073/pnas.1316780110

RIEL-SALVATORE J., \& CLARK G. 2001 - Grave markers. Current Anthropology, 42(4), p. 449-479. doi:10.1086/321801.

RONEN A., VANDERMEERSCH B. 1972 - The Upper Paleolithic sequence in the cave of Qafzeh (Israel). Quaternaria, 16, p. 189-202.

ROUGIER H., CREVECOEUR I., WOLPOFF M. H. 2006 - Lower Third Premolar Rotation in the Krapina Dental Sample. Periodicum Biologorum, 108, 3, p. 269-278.

SAXE A. A. 1970 - Social Dimensions of Mortuary Practices. University of Michigan. Ann Arbor, 240 p.

SCHUH A., DUTAILLY B., COUTINHO NOGUEIRA D., SANTOS F., ARENSBURG B., VANDERMEERSCH B., COQUEUGNIOT H., TILLIER A.-M. 2017 - La mandibule de l'adulte Qafzeh 25 (Paléolithique moyen, Basse Galilée). Reconstruction virtuelle 3D et analyse morphométrique. Paléorient, 43(1), p. 39-59.

SCHWARCZ H.P., GRUN R., VANDERMEERSCH B., BAR-YOSEF O., VALLADAS H., TCHERNOV E. 1988 - ESR Dates for the hominid Burial Site of Qafzeh in Israel. Journal of Human Evolution, 17, p. 733-737.

SOLECKI R. 1971 - Shanidar, the first flower people. New York: A. A. Knopf, 290 p.

TAINTER J.A. 1978 - Mortuary practices and the study of prehistoric social systems. Advances in Archaeological methods and Theory, 1, p. 105-141. 
TCHERNOV E. 1989 - The Middle Paleolithic mammalian sequence and its bearing on the origin of Homo sapiens in the southern Levant. In: O. Bar-Yosef and B. Vandermeersch (Eds.), Investigations in South Levantine Prehistory. Oxford: Archaeopress, BAR, S 497, p. 25-42.

TILLIER A-m. 1999 - Les enfants moustériens de Qafzeh : interprétation phylogénique et paléontologique. Paris : Ed. du CNRS, 239 p.

TRINKAUS E. 1983 - The Shanidar Neandertals. New York: Academic Press, 502 p.

TRINKAUS E. 1984 - Western Asia. In: F.H. Smith, F. Spencer (Eds.), The Origins of Modern Humans: A World Survey of the Fossil Evidence of Modern Humans. New York, Alan R. Liss, p. 251-293.

VALLADAS H., REYSS J.-L., JORON J.-L., VALLADAS G., BARYOSEF O., VANDERMEERSCH B. 1988 - Thermoluminescence dating of the Mousterian 'Proto-Cromagnon' remains from Israel and the origin of modern man. Nature, 331, p. 614-616.

VALLADAS H., MERCIER N., FROGET L., HOVERS E., JORON J.L., KIMBEL W.H., RAK Y. 1999 - TL dates for the Neanderthal site of the Amud Cave, Israel. Journal of Archaeological Science, 26, p. 259-268.

VALLADAS H., JOR J.L., VALLADAS G., ARENSBURG B., BAR-YOSEF, O., BELFER-COHEN, A., GOLDBERG P., LAVILLE H., MEIGNEN L., RAK Y., TILLIER A.M., TCHERNOV E., VANDERMEERSCH B. 1987 Thermoluminescence dates for the Neanderthal burial in Kebara cave, Mt. Carmel, Israel. Nature, 330, p. 159-160.

VALLOIS H. V., VANDERMEERSCH B. 1972 - Le crâne moustérien de Qafzeh (Homo VI). L'Anthropologie (Paris), 76, p. 71-96.
VANDERMEERSCH B. 1966 - Nouvelles découvertes de restes humains dans les couches Levalloiso-moustériennes du gisement de Qafzeh (Israël). Paris : C. R. Acad Sc., 262, D., p. 1434-1436.

VANDERMEERSCH B. 1969a - Les nouveaux squelettes moustériens découverts à Qafzeh (Israël) et leur signification. Paris: C. R. Acad., 268. p. 2562-2565.

VANDERMEERSCH B. 1969b - Découverte d'un objet en ocre avec traces d'utilisation dans le Moustérien de Qafzeh. Bull. Soc. Préhistorique Française, 66, 5, p. 157-158.

VANDERMEERSCH B. 1981 - Les hommes fossiles de Qafzeh (Israël). Paris: Ed. du CNRS, 319 p.

VANDERMEERSCH B. 2006 - Ce que nous apprennent les premières sépultures. C. R. Palevol 5, p. 161-167.

VANDERMEERSCH B., ARENSBURG B., BAR-YOSEF O., BELFER-COHEN A. 2013 - Upper Paleolithic human remains from Qafzeh Cave, Israel. Journal of the Israel Prehistoric Society - Mitekufat Haeven, 43, p. 7-21.

WEINER S., BERNA F., COHEN-OFRI I., SHAHACK-GROSS R., ALBERT M.R., KARKANAS P., MEIGNEN L., BAR-YOSEF O. 2007 Mineralogical distributions in Kebara Cave: diagenesis and its effect on the archaeological record. In: O. Bar-Yosef and L. Meignen (Eds.), Kebara Cave Mount Carmel, Israel: The Middle and Upper Paleolithic Archaeology. Cambridge: American school of Prehistoric Research, Bulletin 49. Peabody Museum of Archaeology and Ethnology, Harvard University, p. 131-146. 